\title{
Chitin and Chitosan Derivatives as Biomaterial Resources for Biological and Biomedical Applications
}

\author{
Saravut Satitsri (D) and Chatchai Muanprasat * \\ Chakri Naruebodindra Medical Institute, Faculty of Medicine Ramathibodi Hospital, Mahidol University, \\ Bang Phli, Samut Prakarn 10540, Thailand; saravut.sat@mahidol.ac.th \\ * Correspondence: chatchai.mua@mahidol.ac.th; Tel.: +66-2-839-5158 \\ Academic Editors: Mohamed Samir Mohyeldin, Katarína Valachová and Tamer M Tamer \\ Received: 21 November 2020; Accepted: 10 December 2020; Published: 16 December 2020
}

\begin{abstract}
Chitin is a long-chain polymer of $N$-acetyl-glucosamine, which is regularly found in the exoskeleton of arthropods including insects, shellfish and the cell wall of fungi. It has been known that chitin can be used for biological and biomedical applications, especially as a biomaterial for tissue repairing, encapsulating drug for drug delivery. However, chitin has been postulated as an inducer of proinflammatory cytokines and certain diseases including asthma. Likewise, chitosan, a long-chain polymer of $\mathrm{N}$-acetyl-glucosamine and D-glucosamine derived from chitin deacetylation, and chitosan oligosaccharide, a short chain polymer, have been known for their potential therapeutic effects, including anti-inflammatory, antioxidant, antidiarrheal, and anti-Alzheimer effects. This review summarizes potential utilization and limitation of chitin, chitosan and chitosan oligosaccharide in a variety of diseases. Furthermore, future direction of research and development of chitin, chitosan, and chitosan oligosaccharide for biomedical applications is discussed.
\end{abstract}

Keywords: chitin; chitosan; chitosan oligosaccharide

\section{Introduction}

\subsection{Chitin}

Chitin is long-chain polymers of $\mathrm{N}$-acetylglucosamine, presence of which has been experimentally confirmed in unicellular (diatoms, protists, fungi) as well as in multicellular (sponges, corals, mollusks, worms and arthropods) organisms [1]. Chitin has been used as supplementary for nutraceutical food, pharmaceutical products as well as 3D scaffolds for biomedicine [2-4] and technological applications [5-8]. Chitin contains thermostability which can be synthesized in the high temperature process [9]. Moreover, chitin has a high tolerance to high chemical concentration that generates the deposition of metals such as copper into chitin via electrochemical procedure at room temperature [10]. The linear polymer of chitin contains $\beta-(1,4)-N$-acetyl-D-glucosamines, which are linked by glycosidic bond. There are three isoforms of chitin including $\alpha$-chitin, $\beta$-chitin and $\gamma$-chitin [11]. The different forms of chitin depend on the arrangement of side chain of backbone. For instance, the structure of $\alpha$-chitin is parallel chain arrangement, whereas the structure of $\beta$-chitin is antiparallel chain arrangement. $\alpha$-chitin is frequently found in nature including exoskeleton of arthropods. $\alpha$-chitin has been frequently applied for tissue engineering $[12,13]$. In contrast to $\alpha$-chitin, $\beta$-chitin is mostly found in squid pen. $\beta$-chitin has been also applied for biomaterial usage such as wound healing $[14,15]$, preservative agents for methylene blue [16], and biological application such as an enhancer of saltiness perception [17]. $\gamma$-chitin has been gathered from cocoon of the moth (Orgyia dubia), and it is found that the structure of $\gamma$-chitin is similar to $\alpha$-chitin rather than $\beta$-chitin, but the surface morphology of $\gamma$-chitin is consisted of microfibers, whereas $\alpha$-chitin and $\beta$-chitin are composed of nanofibers [18]. 


\subsection{Chitosan}

Chitosan is derived from chitin by deacetylation. The major component of chitosan is the mixture between $N$-acetyl-D-glucosamine and $\beta$-(1,4)-linked-D-glucosamine. Chitosan has amounts of $N$-acetyl-D-glucosamine less than $\beta$-(1,4)-linked-D-glucosamine [19]. Chitosan is generally applied as biomaterials, especially for drug delivery system and use in combination with other substances for improving their therapeutic effects $[20,21]$.

\subsection{Chitosan Oligosaccharide}

Chitosan oligosaccharide or chitooligosaccharide is oligomers of chitosan. Chitosan oligosaccharide has the degree of polymerization of $<55$ and molecular weight of $<10 \mathrm{kDa}$ [22]. Chitosan oligosaccharides have a variety of biomedical applications such as drug delivery system [20], functional food [23], as well as the drug against acne vulgaris [24].

In this review, we emphasize the potential application of chitin, chitosan and their oligosaccharides as therapeutics and useful biomaterials in a variety of human diseases. Furthermore, we discuss the limitation of chitin and chitosan oligosaccharide, which will be helpful in guiding future direction of research and development based on these molecules.

\section{Potential Applications of Chitin and Chitosan Oligosaccharides}

\subsection{Neurological and Musculoskeletal Diseases}

Chitin has been proposed as biomaterials for neural treatment. For instance, chitin was utilized with carbon nanotube as a scaffold for neural growth [25]. Chitin as a biological absorbable tube or catheter was effectively used as the bridge for sural nerve grafts in a rat sciatic nerve defect model [26,27]. Chitin hydrogel repaired cartilage injury by protecting chondrocytes from apoptosis and promoting immunomodulation of macrophage and chondrogenesis [28]. The combination of chitin as 2,2,6,6-Tetramethylpiperidine-1-oxyl (TEMPO)-oxidized sacchachitin nanofibers (TOSCNFs) and chitosan-activated platelet-rich plasma (cPRP) induced healing effect in corneal damage by promoting cell proliferation and cell migration in Statens Seruminstitut rabbit corneal (SIRC) epithelial cells [29]. Interestingly, chitin is not only proposed as potential therapy, but also claimed as a molecular marker for neurological diseases. In Alzheimer's disease, chitin is elevated and accumulated within the brain and facilitates a scaffolding for amyloid- $\beta$ deposition [30-32]. Fungal chitin was also detected in brain tissues from Alzheimer's disease patients [33]. Moreover, chitin accumulation was found in multiple sclerosis patients [34]. Interestingly, both microglia and neurons produce $N$-acetylglucosamine polymerization, which causes neurotoxicity in Alzheimer's disease [35]. Furthermore, chitin derived from demosponge Aplysina aerophoba was used as 3D scaffold for human bone marrow-derived stromal cells, and it promoted cell proliferation, cell bridging formation and metabolic activity with no toxicity [36]. Interestingly, chitin derived from demosponge Ianthella basta was applied as a cryopreservative agent that effectively retained adipogenic differentiation in human mesenchymal stromal cells [4].

In contrast to chitin, chitosan and chitosan oligosaccharide have been widely studied for the beneficial effect on neurological diseases, especially Alzheimer's disease. A water-soluble form of chitosan inhibited the production of proinflammatory cytokines including TNF $\alpha$ and IL-6 as well as inducible nitric oxide synthase (iNOS) in human astrocytoma cell line CCF-STTG1 stimulated with IL-1 $\beta$ and $A \beta$ fragments (25-35) [37]. It is known that acetylcholinesterase inhibition is the target for Alzheimer's disease therapy. Chitosan oligosaccharide with $90 \%$ deacetylation and low molecular weight (1 to $5 \mathrm{kDa}$ ) inhibited the protein expression of acetylcholinesterase and $A \beta$ fragment (25-35)-induced acetylcholinesterase activity in PC12 cell lines [38]. Furthermore, caffeic acid conjugated chitosan oligosaccharide effectively inhibited $\beta$-site amyloid precursor protein-cleaving enzyme activity, which was the rate limiting step of $A \beta$ peptide formation in Alzheimer's disease [39]. Interestingly, chitosan oligosaccharide at $500 \mu \mathrm{g} / \mathrm{mL}$ inhibited $\beta$-site amyloid precursor protein cleaving enzyme 1 (BACE1) activity and protein expression in HEK293 APPswe cells [40]. Chitosan oligosaccharide 
inhibited $\alpha \beta$ aggregation, inhibited $A \beta 1-42$ fibrils formation, and induced fibril destabilization in oligomeric $\mathrm{A} \beta$-induced neurotoxicity and oxidative stress in rat hippocampal neurons [41]. In addition, $0.1 \%$ of chitosan oligosaccharide injected into the spatium intermusculare around the biceps femoris muscle inhibited scar formation and promoted regeneration of axons, as well as sensory and motor function in a mouse model of sciatic nerve injury [42]. Interestingly, ingestion of chitosan oligosaccharide (10 mg/kg/day) alleviated inflammatory signal including COX-2 expression in the synovium of an anterior cruciate ligament (ACL) transection-induced osteoarthritis rabbit model [43]. Ingestion of chitosan oligosaccharide at least $200 \mathrm{mg} / \mathrm{kg} /$ day recovered cognitive deficiency in A $\beta 1-42$-induced learning and memory loss rats [44]. Chitosan oligosaccharide also protected hippocampal neuron from A $\beta$ peptide [45]. Furthermore, low molecular weight chitosan activated mitogenic response to platelet-derived growth factor (PDGF) in vascular smooth muscle cells [46].

Chitosan has been applied as biomaterials for neural therapy. For instance, amphiphatic carboxymethyl-hexanoyl chitosan hydrogel increased cell viability and maintained stem-cell-like gene expression of induced pluripotent stem cells applied for corneal reconstruction [47]. Chitosan-polylactide fiber was utilized for nerve growth factor in PC12 cell lines [48]. Chitosan oligosaccharide with calcium silicate and gelatin was applied for implantation of cortical bone repair and bone fracture fixation [49]. Chitosan was coated into nanoparticles for delivering antiamyloid antibody as a drug for Alzheimer's disease. It was found that chitosan coating improved aqueous dispersibility and stability of vehicle during lyophilization [50]. Chitosan in the form of chitosan beads effectively interfered with amyloid- $\beta$ aggregation [51]. Chitosan was utilized as nanocapsules for delivering p38 inhibitor to the brain by nasal administration [52]. Chitosan with polyvinyl alcohol nanofibrous scaffold promoted skeletal muscle regeneration by increasing cell viability, cell adhesion, cell growth, and cell spread on the scaffold [53]. Chitosan with laminin and poly (lactic-co-glycolic acid) effectively repaired nerve injury by promoting nerve regeneration [54]. Chitosan combined to hyaluronate regenerated nerve function defect in parotidectomy rabbit model by promoting scar formation, increasing nerve fibers, thickening myelin sheath, and promoting nerve conduction velocity [55]. Furthermore, chitosan, as chitosan tubes or incorporated to mesenchymal stem cells or keratin, was also utilized for nerve repairing [56-58].

\subsection{Cardiovascular and Hematological Diseases}

Chitin has been incorporated with other substances for treatment of cardiovascular disease. For instance, chitin with glucan and polyphenols from pomegranate recovered endothelial dysfunction by reducing inflammatory marker in the liver and adipose tissues and promoting NO synthase in apolipoprotein E deficient mice (apoE-/-) with high fat diet [59]. Furthermore, chitin combined to graphene oxide as aerogel beads effectively absorbed excessive bilirubin in the blood [60]. Chitin nanogel with rectorite nanocomposite stopped bleeding within $121 \mathrm{~s}$ in rat tail vein, and promoted higher hemostatic activity compared to chitosan-based hemostatic products [61]. Furthermore, Chitin derived from demosponge Ianthella labyrinthus and chitin derived from spider Caribena versicolor were effectively served as a 3D scaffold for culturing induced pluripotent stem-cell-derived cardiomyocytes as well as commercial extracellular matrix [62,63].

It has been known that orally intake of $5 \%$ chitosan in the diet reduces serum cholesterol and atherogenesis inhibition in apolipoprotein E-deficient mouse model [64]. Chitosan as a supplemental diet downregulated the markers involving obesity such as leptin in high fat diet rats [65]. Chitosan oligosaccharide decreased serum cholesterol by promoting accumulation of cholesterol in liver, bile, and feces with reverse cholesterol transport pathway [66]. It is known that chitosan oligosaccharide reduces serum cholesterol. Chitosan oligosaccharide increased cell surface expression of low-density lipoprotein receptor (LDLR) and increased lipid droplets in HepG2 cells, suggesting that chitosan oligosaccharide effectively reduced serum lipids by facilitating the accumulation of lipids into the cells [67]. Furthermore, chitosan oligosaccharide downregulated mRNA expression of LPS-induced E-selectin and intercellular adhesion molecule-1, which are a part of the inflammatory responses in endothelial cells via MAPK inhibition [68]. Oral intake of chitosan oligosaccharide also reduced the 
marker of atherosclerosis including the lesion area in aorta or plaque area in aortic roots, and greatly reduced cholesterol and triglyceride in apolipoprotein E deficient mice (apoE-/-) [69]. The combination of chitosan oligosaccharide ingestion and exercise such as running improved immune system by increasing spleen to body weight ratio and lung to body weight ratio compared to water gavage only in Sprague-Dawley (SD) rats [70]. Interestingly, chitosan improved blood perfusion and promoted neovascularization by modulation of gut microbiota in a mouse hindlimb ischemia model [71]. Furthermore, chitosan was used as a vehicle for drug delivery for transportation of doxorubicin to improve the treatment of blood malignancies [72]. Chitosan in the form of synthetic CD47 antibodychitosan/hyaluronic acid polyelectrolyte complex inhibited atherosclerotic plaques with downregulated NLRP3 inflammasome expression in apolipoprotein E deficient mice (apoE-/-) [73].

\subsection{Respiratory Diseases}

It is well known that penetration of chitin into human bodies causes the production of chitinase, the enzyme that modulates immune response, and chitinase-like proteins YKL-40. YKL-40 was associated with increased severity in asthmatic patients [74]. YKL-40 level was also positively correlated with neutrophils, sputum IL-1 $\beta$, and plasma IL-6 [75]. Moreover, chitin from fungi induced eosinophilic infiltration in a mouse model [76]. Chitin also promoted proinflammatory response by inducing proinflammatory cytokine release including IL-25 and IL-33 in human bronchial epithelial cells [77]. Chitin has been known as an adjuvant for immune response. It was demonstrated that chitin from house dust mite promoted airway hypersensitivity in ovalbumin-induced airway inflammation via a TLR-2 dependent pathway [78]. Furthermore, it is known that chitin is the major component of fungi in their cell wall. Chitin exposure induced macrophage activation which upregulates the expression of chitin degrading enzyme chitotriosidase [79]. Chitotriosidase was also involved in lung diseases such as tuberculosis, chronic obstructive lung diseases [80]. Apart from chitotriosidase, acute exposure to the fungal pathogen Aspergillus fumigatus promoted the function of acidic mammalian chitinase, which determined the severity of fungal asthma [81]. Therefore, inhibition of chitotriosidase and acidic mammalian chitinase is regarded as a drug target for respiratory diseases [82]. However, it has been shown that a chitin analog AVR-25 partially alleviated pulmonary dysregulation in a hyperoxia-induced experimental mouse model of bronchopulmonary dysplasia by suppressing inflammation [83]. These findings indicate that chitin may have both beneficial and detrimental effects.

In contrast to chitin, chitosan oligosaccharides have been demonstrated to have potential beneficial effects on respiratory diseases. Oral intake of chitosan oligosaccharide $(500 \mathrm{mg} / \mathrm{kg})$ at a single dose alleviated particulate matter (PM) 2.5-induced lung inflammation by decreasing lactate dehydrogenase, IL-8, and TNF- $\alpha$ in PM 2.5-induced rat model [84]. Chitosan oligosaccharide (100 kDa and $90 \%$ deacetylation) prevented inflammation, oxidative stress and apoptosis in the lung tissues of blast injury-induced mice by diminishing protein expression of p38 and ADMA (an inhibitor of endogenous nitric oxide synthase that positively correlated with hypertension) and recovering dimethylarginine dimethylaminohydrolase 1 (DDAH1), a hydrolase of ADMA [85]. Furthermore, oral intake of $16 \mathrm{mg} / \mathrm{kg} /$ day of low molecular weight chitosan oligosaccharide reduced IgE-induced airway inflammation in mice by downregulating both protein level and mRNA level of proinflammatory cytokines including IL-4, IL-5, IL-13, and TNF- $\alpha$ [86].

\subsection{Renal Diseases}

There are reports demonstrating the effect of chitin on renal diseases. Oral ingestion of chitin as surface-deacetylated chitin nano-fiber $(40 \mathrm{mg} / \mathrm{kg} / \mathrm{day})$ reduced uremic toxins including oxidants in nephrectomized rats [87]. However, upregulated YKL-40 level in urine and plasma represents the biomarker of acute kidney injury [88,89]. In contrast, chitosan and chitosan oligosaccharide have potential therapeutic effects on kidney diseases. The combination of chitosan with gynostemma and motherwort was used for protecting chronic renal failure by inhibiting inflammation in adenine-induced rat chronic renal failure [90]. Chitosan incorporated with gallic acid reduced the formation of calcium 
oxalate crystal, which was mainly a kidney stone, and had antioxidative effects [91]. Chitosan as a cat diet improved kidney function and quality of life in elderly cats with 3 and 4 International Renal Interest Society (IRIS) stages [92]. It was also shown that chitosan oligosaccharide improved kidney function in streptozotocin-induced diabetic rats [93]. It was found that $0.1 \%$ chitosan oligosaccharide with more than $90 \%$ deacetylation prevented glycerol-induced acute renal failure in rats by decreasing renal dipeptidase activity, a diagnostic marker of acute renal failure [94]. Furthermore, chitosan oligosaccharide with carboxymethyl group relieved renal injury induced by doxorubicin and promoted antioxidative effects in rats [95]. Interestingly, chitosan oligosaccharide triggered G2/M phase arrest, promoted endoplasmic reticulum stress pathway, and inhibited tumor growth in human renal carcinoma cells and xenograft tumor models [96]. Moreover, chitosan oligosaccharide had a chelating property which detoxified depleted uranium cytotoxicity in human renal proximal tubular epithelial cells [97]. Recently, chitosan oligosaccharide at the concentration of 50 and $100 \mu \mathrm{g} / \mathrm{mL}$ was shown to reduce renal cyst growth via CaMKK $\beta$-induced AMPK activation without cytotoxicity [98]. Furthermore, the detoxification property of chitosan has been applied in hemodialysis patients. The ingestion of chitosan decreased the level of indoxyl sulfate and phosphate by binding to these molecules [99]. Chitosan has also been applied as siRNA delivery system targeting kidney. For instance, chitosan nanoplex effectively covered siRNA for knocking down PDGF-B and PDGFR-beta [100]. Chitosan was also used as biomaterials in combination with collagen for culturing human renal proximal tubular cells [101]. The potential beneficial effects of chitosan oligosaccharide on kidney diseases have been also reviewed elsewhere [102].

\subsection{Gastrointestinal Diseases and Gut Microbiota}

Many previous studies demonstrated the potential effects of chitin and chitosan oligosaccharide on gastrointestinal disease. It was shown that chitin protected intestinal barrier function in DSS-induced colitis in a protochordate model [103]. Chitin combined with glucan (chitin-glucan complex) was used as a prebiotic. This chitin-glucan complex improved the growth of Bifidobacterium, a probiotic, in a rat model [104]. Interestingly, intake of $4.5 \mathrm{~g} /$ day of chitin-glucan in food for 3 weeks increased beneficial microbiota metabolites including butyric, iso-valeric and caproic acids without major changes in gut microbiota composition [105]. Chitin has also been applied as surface-deacetylated chitin nanofiber. It was shown that oral intake of $80 \mathrm{mg} / \mathrm{kg} /$ day of surface-deacetylated chitin nanofiber decreased hepatic injury and oxidative stress in a nonalcoholic steatohepatitis model of rats [106].

Chitosan and chitosan oligosaccharide have beneficial effects on gastrointestinal tract, especially as nutritional supplements for animals and food supplements for human. In livestock, chitosan oligosaccharide has been used as feed additives in animal diet. It was shown that $100 \mathrm{mg} / \mathrm{kg}$ of dietary chitosan oligosaccharide supplementation promoted growth performance, reduction of diarrhea, nutrient digestibility and attenuation of E.coli K88 infection in weaning pigs [107,108]. The combination of chitosan and zinc at the dose of $100 \mathrm{mg} / \mathrm{kg}$ as a feed additive in diet also promoted the activities of digestive enzymes such as amylase, reduced diarrhea and improved growth performance in weaning pigs [109]. However, chitosan mixed with probiotic such as Enterococcus faecalis did not significantly reduce severity of diarrhea and affect growth performance in E.coli K88-inoculated weaning pigs [110]. Moreover, high molecular weight chitosan oligosaccharide (20 to $30 \mathrm{kDa}$ ) just only increased ZO-1 expression and decreased the mRNA expression of IL-1 $\beta$ and TNF $\alpha$ in weaning pigs without affecting diarrhea, average dairy gain, gain to feed ratio, and antioxidant capacity [111], suggesting that specific forms of chitosan oligosaccharide gives the therapeutic effects in weaning pig. Furthermore, low molecular weight chitosan oligosaccharide $(8 \mathrm{kDa})$ with $90 \%$ deacetylation improved gut absorption, increased villus length and promoted intestinal cell proliferation in weaning pig [112]. Oral intake of $200 \mathrm{mg} / \mathrm{kg} /$ day of chitosan oligosaccharide in drinking water also protected gut from the modulation of glucose metabolism and gut dysbiosis in diabetic mice [113]. At a cellular level, $100 \mu \mathrm{g} / \mathrm{mL}$ of low molecular wight chitosan oligosaccharide (approximately $5 \mathrm{kDa}$ ) accelerated tight junction assembly and inhibited cholera toxin-induced intestinal fluid secretion via CaSR-PLC-IP3 
receptor channel-mediated AMPK activation in intestinal epithelial cells [114]. Chitosan oligosaccharide suppressed mRNA expression of proinflammatory cytokines, and inhibited the downregulation of PPAR $\gamma$ in palmitic acid-induced HepG2 cells and high fat diet mice [115]. Many reports reveal that chitosan and chitosan oligosaccharide modulate gut microbiota. Chitosan prevented gut dysbiosis and inhibited the activation of toll-like receptor and nod-like receptor signaling pathway in high fat diet rats [116]. However, molecular weight and degree of deacetylation of chitosan oligosaccharide are major determinants of effects on human gut microbiota composition as well as therapeutic effects. For instance, a highly deacetylated chitosan oligosaccharide decreased Bifidobacterium spp., E. rectale/C. coccoides, C. histolyticum and Bacteroides/Prevotella populations in human gut [117]. Chitosan oligosaccharide with $>95 \%$ deacetylation reduced Lactobacillus, Bifidobacterium and Desulfovibrio, deleterious bacteria that were correlated with inflammatory bowel disease [118], and increased abundance of Akkermansia that was a good bacteria [119]. The $3 \mathrm{kDa}$ chitosan oligosaccharide diminished gut dysbiosis and downregulated mRNA expression of proinflammatory cytokines in azoxymethane and dextran sulfate sodium-induced mouse model of colorectal cancer [120]. Moreover, chitosan oligosaccharide ameliorated hepatic steatosis and liver injury, and reduced triglyceride and free fatty acid in diet-induced obese mice by downregulating inflammatory genes and modulation of gut microbiota [121]. Furthermore, chitosan protected liver from ischemia-reperfusion injury via regulating Bcl-2/Bax, TNF- $\alpha$ and TGF- $\beta$ expression [122], prevented lipid metabolic disorder by combination with Ganoderma polysaccharide [123], alleviated menopausal symptoms [124], and protected the gut from ischemic symptoms [71]. High molecular weight chitosan was also prepared as nanoparticles for drug delivery in gut. For instance, $400 \mathrm{kDa}$ chitosan integrated to insulin loaded chitosan nanoparticles prolonged bioavailability of insulin release [125]. Interestingly, chitosan nanoparticle was also used as a food supplement for improvement of growth performance and immunity in weaning pigs [126].

Apart from chitin, chitosan, and chitosan oligosaccharide, there are other polysaccharides that have therapeutic effects on gut. For instance, mannan oligosaccharide $(10 \mu \mathrm{M})$ promoted intestinal barrier function in T84 cells via AMPK activation $[127,128]$. Fructo-oligosaccharide $(0.1 \mathrm{mg} / \mathrm{mL})$, a prebiotic, accelerated intestinal tight junction reassembly via AMPK activation in T84 cells [129].

\subsection{Endocrinological Diseases and Diabetes Mellitus}

Chitin combined with other compounds has been shown to possess therapeutic effects. For instance, oral intake of $4.5 \mathrm{~g}$ /day of chitin combined with glucan reduced oxidized low-density lipoprotein in human subjects [130]. Furthermore, chitin has been applied as a biomaterial for prolonging bioavailability. For instance, injectable thermo-sensitive hydrogel based on hydroxypropyl chitin was incorporated to salmon calcitonin to extend long-term sustained salmon calcitonin release [131].

Likewise, chitosan has been combined with other compounds that possess antidiabetic effects. For instance, 3-O-sulfochitosan was reported to reduce blood glucose in diabetic rats [132]. Chitosan combined with metformin, a type 2 diabetic drug, synergistically enhanced drug efficacy and reduced lethal effects of drug overdose [133]. Furthermore, chitosan oligosaccharide has been applied for drug delivery system in diabetes. For instance, chitosan-microcapsulated insulin, chitosan-stabilized selenium nanoparticles, chitosan encapsulated resveratrol, chitosan coating of $\mathrm{TiO}_{2}$ nanotube arrays for metformin, chitosan nanoparticle and chitosan hydrogel were used for improving diabetic therapy [134-142]. Interestingly, the development of chitosan oligosaccharide as a drug or supplement for diabetic treatment has been studied for a decade. The proteomic data demonstrated the antidiabetic effects and anti-obesity of orally intake chitosan oligosaccharide in ob/ob mice [143]. Oral intake of chitosan oligosaccharide ( $>90 \%$ deacetylation; $500 \mathrm{mg} / \mathrm{kg}$ ) promoted insulin sensitivity in streptozotocin-induced diabetic rats. Chitosan oligosaccharide $(100 \mathrm{mg} / \mathrm{L})$ also promoted cell proliferation in primary culture islet cells and pancreatic $\beta$-cell lines [144]. Moreover, the low molecular weight chitosan oligosaccharide $(\sim 1.2 \mathrm{kDa})$ promoted cell proliferation in primary culture islet cells and pancreatic $\beta$-cell lines as well as improving insulin sensitivity greater than the high molecular weight chitosan oligosaccharide [145]. Moreover, chitosan oligosaccharide with a molecular weight of $1.3 \mathrm{kDa}$ and $55 \%$ deacetylation was used 
as an oral insulin delivery system that showed the highest effect of glucose reduction [146]. Furthermore, chitosan oligosaccharide has been used as a food supplement for diabetic treatment. For instance, GO2KA1, a commercial chitosan oligosaccharide supplement, had a beneficial effect on glucose control in subjects with prediabetes by regulating postprandial glucose [147]. GO2KA1 promoted glucose uptake into intestinal epithelial cells, enhanced adipocyte differentiation, and upregulated PPAR $\gamma$ expression [148]. GO2KA1 has been used in clinical trials. It was found that GO2KA1 effectively reduced postprandial blood glucose levels in subjects with impaired glucose tolerance and impaired fasting glucose [149]. However, it remains unclear whether chitosan oligosaccharide has a direct or indirect antidiabetic effect. It was also shown that chitosan oligosaccharide exerted antidiabetic effects via gut microbiota modulation [116]. Chitosan oligosaccharide was used as a supplementary drug for improving the glycemic control of sitagliptin in type 2 diabetes mellitus (T2DM) by reducing insulin resistance and proinflammatory cytokines, and increasing insulin sensitivity [150]. Chitosan oligosaccharide combined with xanthine derivatives improved liver and kidney functions compared to pioglitazone, a standard antidiabetic drug [151]. Chitosan oligosaccharide also upregulated the expression of browning genes in white adipose tissues and thermogenesis of brown adipose tissues, which consequently reduced obesity in obese rats [152]. Chitosan oligosaccharide was applied in the form of tablet that had therapeutic effects on the regulation of serum lipid level and downregulation of cholesterol excretion genes including CYP7A1, LXR, PPAR- $\alpha$, and LDLR in high fat diet-induced hyperlipidemic rats [153]. Moreover, chitosan oligosaccharide reduced endoplasmic reticulum stress in HepG2 cell lines [154]. Interestingly, chitosan oligosaccharide did not induce any hepatotoxic effects or lipid metabolism disorders in normal Sprague-Dawley rats [155].

\subsection{Inflammatory Diseases}

Inflammation is generally a crucial defense mechanism of human body against pathogens, injuries, or toxins. In addition, there are several diseases related to hyperinflammatory responses such as inflammatory bowel disease and systemic lupus erythematosus. Chitin has been applied as a biomaterial for suppressing inflammation. For instance, chitin nanofibril was used for inhibiting skin inflammation in the experimental atopic dermatitis mouse model by suppression of NF- $\mathrm{KB}$ [156]. However, many reports have demonstrated that chitin is an inflammatory inducer. For instance, chitin induced inflammation in peripheral blood mononuclear cells from obese subjects ex vivo [157]. Chitin triggered inflammatory responses via type 2 innate lymphoid cells and $\gamma \delta \mathrm{T}$ cell activation [158]. Furthermore, chitin enhanced IL-33 secretion and consequently IL-1 $\beta$ secretion by dendritic cells in ovalbumin-induced asthmatic mice [159]. However, Wagener el al demonstrated that fungal chitin triggered anti-inflammatory cytokines including IL-10 via NOD2 and TLR-9 activation, indicating that chitin exposure triggered inflammatory responses together with anti-inflammatory responses as negative feedback to regulate the inflammatory process. Interestingly, low size chitin (1-10 $\mu \mathrm{m})$ induced secretion of IL-10, an anti-inflammatory cytokine, at low concentrations, but induced secretion of $\mathrm{TNF} \alpha$, a proinflammatory cytokine, at high concentrations [160]. However, chitin nanofibrils, nanorods structure of chitin, downregulated proinflammatory cytokines including TNF- $\alpha$, IL-1 $\alpha$, IL-1 $\beta$, IL-6, and IL-8, and concomitantly upregulated antimicrobial peptide $\beta$-defensin 2 in human keratinocytes (HaCaT cells) [161].

Chitosan and chitosan oligosaccharide have been reported as anti-inflammatory agents. Chitosan recovered intestinal barrier function in DSS-induced colitis by stimulating expression of tight junction proteins such as claudin-1, occludin, and ZO-1 [162]. Chitosan downregulated chitinase enzyme YKL-40 in primary human macrophages [163]. Carboxymethyl chitosan was shown to have anti-inflammatory effects in mice [164]. Likewise, it was shown that an oral intake of chitosan oligosaccharide $(20 \mathrm{mg} / \mathrm{kg} / \mathrm{day})$ alleviated DDS-induced acute and chronic colitis in mice by inhibiting an NF- $k B$ pathway [165]. Moreover, chitosan oligosaccharide downregulated NF- $\mathrm{kB}$ downstream targets such as COX-2 and upstream targets such as TLR-4 in lipopolysaccharide-induced inflammation in intestinal epithelial cells [166]. Furthermore, 50-200 $\mu \mathrm{g} / \mathrm{mL}$ of a highly $\mathrm{N}$-acetylated chitosan oligosaccharide inhibited 
protein expression of PI3K/Akt signaling pathway, which was involved in proinflammatory cytokine production in RAW 264.7 macrophage cells [167]. The physiochemical properties as well as preparation processes of chitosan oligosaccharide influence its anti-inflammatory effect. It was shown that $42 \%$ fully deacetylated oligomers plus 54\% monoacetylated oligomers of chitosan oligosaccharide alleviated inflammation, whereas $50 \%$ fully deacetylated oligomers plus $27 \%$ monoacetylated oligomers promoted inflammation in RAW 264.7 macrophage cells [168]. Furthermore, chitosan oligosaccharide protected against shrimp tropomyosin-induced food allergy by downregulation of IL-4, IL-5, and IL-13 and upregulation of IFN- $\gamma$ in sensitized mice [169]. Chitosan oligosaccharide $(200 \mathrm{mg} / \mathrm{kg})$ prevented heat stress-induced inflammatory responses by decreasing liver IL-1 $\beta$ concentration [170]. Apart from chitin and chitosan oligosaccharide, fructooligosaccharide and yeast polysaccharide had an inhibitory effects on TNF- $\alpha$-induced GLP-1 secretion in L cells and DSS-induced colitis in mice, respectively $[171,172]$.

\subsection{Cancer}

Chitin has promise for development as an anti-cancer agent and a vehicle for anticancer drug delivery. It was shown that chitinase-3 like protein-1 (CHI3L1), which was upregulated and promoted proinflammatory mediators in breast cancer cells, was inhibited by chitin $[173,174]$. Chitin downregulated vascular endothelial growth factor C (VEGF-C) synthesis that was related to tumor angiogenesis [175]. In addition, chitin has been prepared in various forms that can counteract cancer. For instance, silver embedded chitin nanocomposites promoted cytotoxicity in human breast cancer (MCF-7) cells [176]. Chitin-glucan-aldehyde-quercetin conjugation induced cytotoxicity in a macrophage cancer cell line (J774) with no toxic effect on peripheral blood mononuclear cells (PBMCs) [177]. Furthermore, chitin has been used for anticancer drug delivery. For instance, chitin with poly L lactic acid composite nanogel containing doxorubicin induced cytotoxicity in liver cancer HepG2 cells and enhanced anticancer drug efficacy [178]. Chitin nanoparticles were loaded with anticancer natural product ellagic acid, which inhibited breast cancer cell growth [179].

Interestingly, there are several reports demonstrating the potential antitumor effect of chitosan and chitosan oligosaccharide. For instance, chitosan decreased cell proliferation, stimulated apoptotic effects, and decreased cell adhesion in human melanoma cell lines including SKMEL38 cells, RPMI7951 cells, and A375 cells, respectively [180]. Oral intake of $500 \mathrm{mg} / \mathrm{kg} / \mathrm{day}$ of chitosan oligosaccharide abolished tumor progression in colitis-associated colorectal cancer via NF- $\mathrm{kB}$ inhibition and AMPK activation [181]. Chitosan oligosaccharide modulated cell autophagy that inhibited cell proliferation of A549 lung cancer cell line [182]. Low molecular weight chitosan oligosaccharide induced cytotoxic effects, cell cycle arrest and apoptosis in oral squamous cell carcinoma (SCC) cells without any effects on noncancerous keratinocyte (HaCaT) cell lines [183]. Chitosan also had anticancer activity in various types of cancer such as human ovarian cancer, breast cancer and cervical carcinoma [184-186]. Chitosan was combined with other compounds to enhance anticancer effects. For instance, carboxymethyl chitosan inhibited tumor growth in mouse hepatocarcinoma by abolishing tumor angiogenesis [187]. Chitosan selenate inhibited cancer cell viability and promoted cancer cell apoptosis in lung cancer A549 cells [188]. Furthermore, 5-fluorouracil-conjugated chitosan oligosaccharide plus vanillin, indomethacin-conjugated chitosan oligosaccharide nanoparticles, and thioguanine-conjugated chitosan graphene oxide were applied for cancer drug delivery systems [189-191].

\subsection{Aging}

The world population is beginning to age. Antiaging agents have been developed to support the aging society. Oxidative stress is a major promoting factor of aging. Antioxidant compounds are recognized as therapeutic agents for delay aging. Chitin had a scavenging activity to chelate 1,1-diphenyl-2-picrylhydrazyl radicals [192]. Chitin was also used as a biomaterial for antioxidant agent container. For instance, chitin nano-crystal complex containing melatonin, vitamin $\mathrm{E}$, and $\beta$-glucan reduced wrinkle and yielded a better skin appearance in human subjects [193]. Chitin-glucan-aldehydequercetin conjugates also had a potent antioxidant activity [177]. Interestingly, chitin nanofibrils and 
nanochitin can mimic the extracellular matrix, so these agents have been applied as cosmeceuticals against aging [194].

Chitosan oligosaccharide has widely been used as antioxidative agents. Chitosan supplementation reduced oxidative stress in the heart tissues and maintained glutathione reductase, glutathione peroxidase, and reduced glutathione in young and aged rats [195]. Chitosan oligosaccharide restored redox balance in LPS-induced oxidative stress [196]. Chitosan oligosaccharide with $90 \%$ deacetylation potently inhibited oxidative stress in rats [197]. Several studies confirmed the therapeutic effects of chitosan and chitosan oligosaccharide on oxidative stress in many types of animal models including aging mice, weaning pig, hydrogen peroxide-induced rats, and heat-stressed rats [198-201]. Interestingly, chitosan oligosaccharide recovered aging-induced liver dysfunction via the upregulation of Nrf2 antioxidant signaling [202]. Chitosan-gallic acid, synthetic carboxymethyl chitosan, chitosan-ellagic acid and selenide chitosan sulfate have also been demonstrated to have an antioxidant activity [203-206].

\subsection{Infectious Disease}

Generally, chitin has no antipathogenic effects [207]. Although, chitin derived from demosponges Ianthella flabelliformis was applied as drug delivery material for antibiotic drug including decamethoxine [208]. Additionally, many reports have demonstrated the antibacterial effects and antifungal effects of chitosan oligosaccharide. Chitosan oligosaccharide $(10 \mathrm{kDa})$ had the highest antimicrobial effect with minimum inhibitory concentration values of $32-64 \mu \mathrm{g} / \mathrm{mL}$ on Propionibacterium acnes [24]. In addition, low-molecular-weight chitosan oligosaccharide inhibited bacterial activity, biofilm formation and hemolytic activity of Staphylococcus aureus [209]. In vivo and in vitro models showed that chitosan reduced Cryptosporidium parvum oocyst viability and Cryptosporidium parvum multiplication, respectively [210,211]. Furthermore, chitosan oligosaccharide killed Candida auris in both nonaggregative form (NCPF 8973) and aggregative form (NCPF 8978) [212]. Interestingly, chitosan oligosaccharide with an averaged degree of polymerization of 32 and a fraction of acetylation of 0.15 inhibited Candida spp. growth [213]. Interestingly, chitosan oligosaccharide had antifungal effects against Ceratocystis fimbriata by promoting fungal apoptotic cascades including ROS accumulation, mitochondrial dysfunction, and caspase activation [214]. Furthermore, $\mathrm{N}, \mathrm{N}, \mathrm{N}$-trimethyl-O-(ureidopyridinium) acetyl chitosan derivatives, chitosan oligosaccharide functionalized silver nanoparticles, chitosan oligosaccharide-capped gold nanoparticles, and chitosan oligosaccharide- $N$-chlorokojic acid mannich base polymer were shown to hold promise for antibacterial application [215-218].

\subsection{Trauma/Wound}

Chitin has been applied as a major component of biomaterials for wound healing. Chitin was used for suturing because of its safety and rapid tissue recovery [219]. Chitin derived from demosponges Ianthella labyrinthus and Aplysina archeri was applied as alternative gauze fabrics, and it effectively absorbed blood into chitinous microtubes [62,220]. Additionally, several studies improved efficacy of chitin for wound healing by integration with other components. For instance, diacetyl chitin, a novel absorbable surgical suture, was ultimately absorbed within 42 days after suturing without tissue reaction, and promoted faster skin regeneration in vivo [221]. Chitin hydrogel, acrylamide-modified- $\beta$-chitin with alginate dialdehyde, showed promising properties including biocompatibility, biodegradability and injectability, and effectively accelerated wound healing [222]. In addition, sacchachitin nanofibers accelerated blood clotting times by $30 \mathrm{~s}$ and significantly promoted wound healing in streptozotocin-induced diabetic rats [223]. Interestingly, chitin accelerated wound healing via a MyD88-dependent pathway, followed by a TGF- $\beta /$ Smad pathway [224]. Furthermore, Pseudomonas aeruginosa-infected wounds in $\mathrm{db} / \mathrm{db}$ diabetic mice were diminished by cleaning with cleansing agent hypochlorous acid and covering with silver nanoparticle/chitin in the form of nanofiber sheet [225]. Chitin-amphiphilic ion/quaternary ammonium salt having antibacterial and antipollution effects was also used for wound healing [226]. Chitin-lignin gels, as an extracellular matrix-like scaffold, were applied as wound dressing material that had a property of sustainable drug release especially 
antibiotics [227]. Recently, chitin has been applied as a tissue adhesive. Chitin nanowhiskers with a Schiff base crosslinking hydrogel of carboxymethyl chitosan and dextran dialdehyde enhanced tissue adhesive strength with no cytotoxicity and with antibacterial effects [228]. Furthermore, chitin nanofibrils have been also applied as biomaterials. For instance, addition of $0.5 \%$ chitin nanofibrils into chitosan sponges promoted the stopping of arterial bleeding faster than commercial hemostatic agents [229].

Likewise, chitosan and chitosan oligosaccharide have been demonstrated as a biomaterial for promoting wound healing. For instance, chitosan oligosaccharide incorporated with silver nanoparticles accelerated wound healing by activating TGF- $\beta /$ Smad pathway $[230,231]$. Chitosan was further used as a nanoparticle for carrying drugs including pioglitazone, heparin and bemiparin for wound healing application especially for diabetic wounds [232,233]. Chitosan-polyurethane hydrogel membrane in combination with mononuclear bone marrow fraction cells was used for wound healing in a diabetic rat model [234]. Furthermore, chitosan-curcumin complex, quaternary ammonium chitosan nanoparticles, carboxymethyl chitosan plus alginate were developed as biomaterials with high potential for wound healing application [235-237].

\section{Limitation}

The limitation in utilization of chitin is its potential toxicity in the human body, especially in the respiratory tract. According to previous studies, chitin exposure in the respiratory tract induced chitinase production, which was positively correlated to asthma [76]. In addition, chitin exposure to the respiratory tract can trigger innate immune response, especially macrophage and eosinophil activation. Furthermore, chitin is insoluble in water. However, oral intake of $5 \%$ chitin in a diet for 13 weeks showed no apparent toxicity in the gastrointestinal tract in rats [238]. Therefore, it appears that the adverse effects of chitin depend on the route of exposure.

In contrast to chitin, several studies have reported that oral ingestion of chitosan and chitosan oligosaccharide shown minimal toxicity $[239,240]$. Furthermore, chitosan oligosaccharide can dissolve in water. Chitosan and chitosan oligosaccharide have been approved as food additives by the American Food and Drug Administration (FDA). The potential systemic toxic effects of chitosan oligosaccharide are minimal.

\section{Conclusions and Future Perspectives}

Currently, chitin and chitosan have been used as a biomaterial for wound healing and drug delivery. Moreover, chitin and chitosan have been integrated with other chemicals to improve efficacy in therapeutic applications. Interestingly, the thermostability of chitin, chemical tolerance of chitin, and accessible natural source of chitin shed light on various procedures for biomaterial generation. Based on these advantageous properties, further development of chitin is needed to provide better biomaterials applicable for various human diseases. However, the development of chitin for medical applications requires further steps to improve safety and efficacy. A summary of potential applications and adverse effects of chitin is shown in Figure 1. 


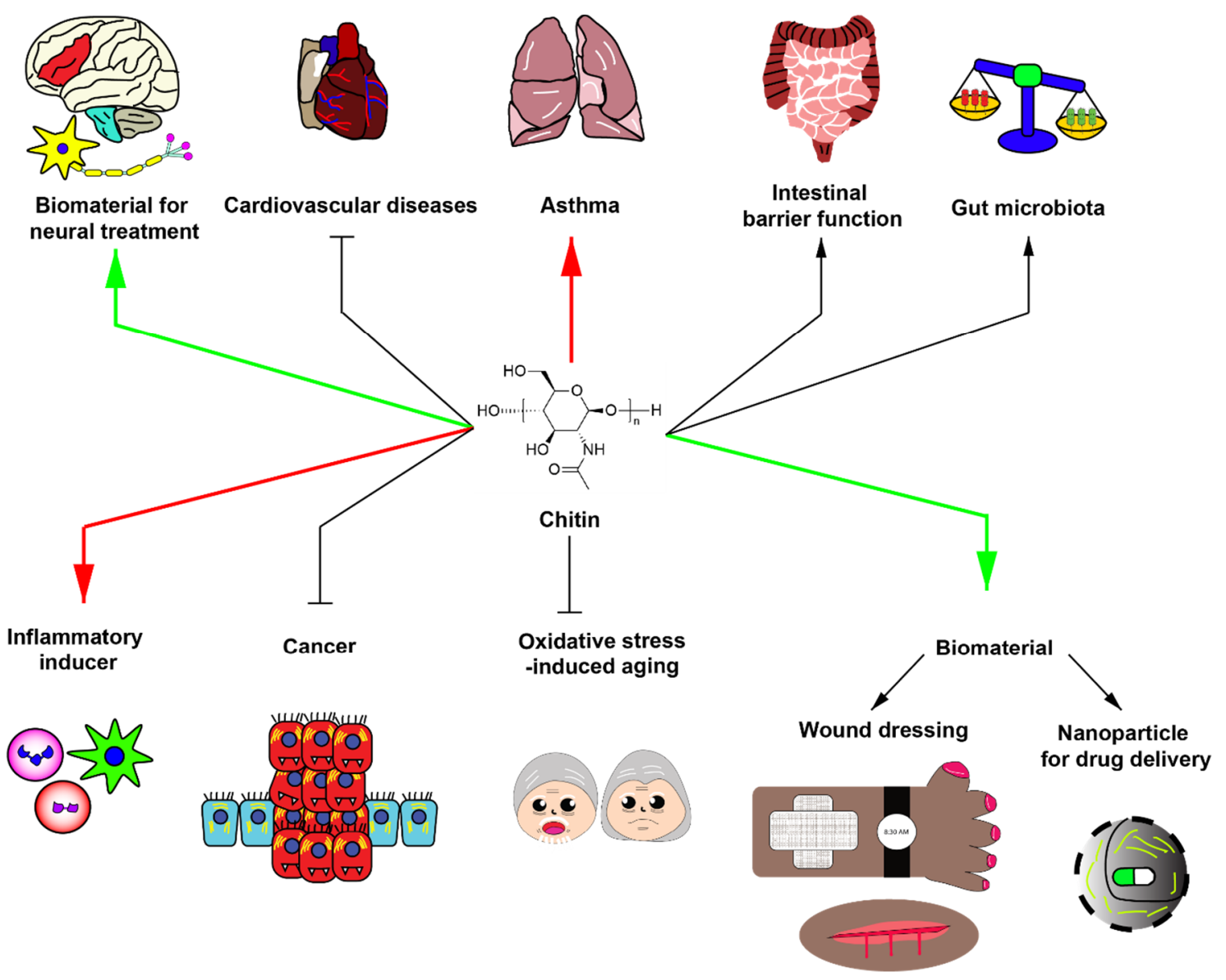

Figure 1. Potential roles of chitin in biomedical applications. Green arrows indicate potential beneficial applications of chitin with strong evidence. Red arrows demonstrate potential detrimental effect of chitin with strong evidence. Black arrows delineate the potential effects of chitin with slight evidence. Chitin has been generally utilized as biomaterials for neural treatment, wound dressing and nanoparticle component for drug delivery. In addition, chitin has been used for improving intestinal barrier function, increasing beneficial gut microbiota, partially inhibiting cardiovascular diseases, inhibiting cancer growth, and inhibiting oxidative stress-induced aging. However, chitin may have detrimental effects. For instance, chitin exposure can induce asthma and acts as an inflammatory inducer.

Chitosan oligosaccharide has been applied for treatment of several types of human diseases or pathological conditions. Chitosan oligosaccharide with low molecular weight $(<5 \mathrm{kDa})$ and $>90 \%$ degree of deacetylation inhibits inflammatory responses by promoting anti-inflammatory pathways. Furthermore, chitosan oligosaccharide has antioxidative and anticancer effects. Interestingly, chitosan oligosaccharide, as a prebiotic for gut microbiota, modulates gut microbiota leading to the alleviation of systemic diseases, especially atherosclerosis. Biological effects of these compounds are determined by degree of deacetylation and polymerization, which remains the challenge in the development of chitosan oligosaccharide as an effective food supplement. Further investigations are needed to reveal detailed molecular/cellular mechanisms of biological effects of these polymers especially the role of their prebiotic effect and their direct effect on disease-specific cells or drug targets. Finally, since chitosan oligosaccharide possesses antioxidative effects, its potential application as an anti-aging agent should be further investigated. Potential applications and adverse effects of chitosan and chitosan oligosaccharide are summarized in Figure 2. 


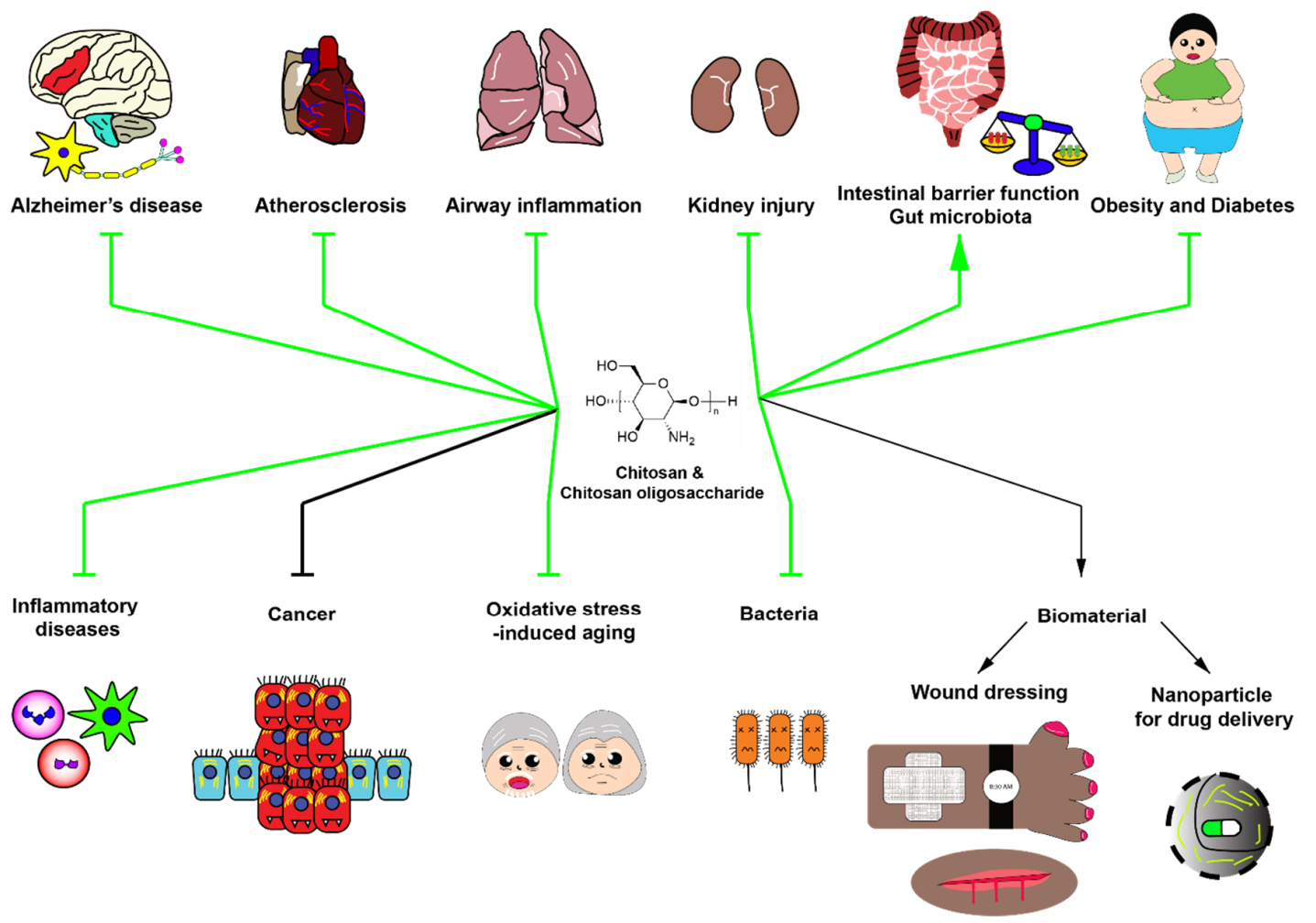

Figure 2. Potential roles of chitosan and chitosan oligosaccharide in biomedical applications. Green arrows indicate the beneficial applications of chitosan and chitosan oligosaccharide with strong evidence. Black arrows indicate the potential effects of chitosan and chitosan oligosaccharide with slight evidence. Chitosan and chitosan oligosaccharide have numerous beneficial effects including anti-Alzheimer's disease, anti-atherosclerosis, anti-inflammatory diseases, kidney injury alleviation, improvement of intestinal barrier function, enhancement of beneficial gut microbiota, alleviation of obesity and type II diabetes, prevention of inflammatory diseases, anticancer activity, antiaging activity and antibacterial activity, and serve as valuable biomaterials for wound dressing and drug delivery.

Author Contributions: Conceptualization, S.S. and C.M.; resources, S.S.; data curation, S.S.; writing-original draft preparation, S.S.; writing-review and editing, C.M.; funding acquisition, S.S. and C.M. All authors have read and agreed to the published version of the manuscript.

Funding: This research was funded by Thailand Research Fund, National Research Council of Thailand and Mahidol University, TRG6280002 (S.S.) and Thailand Research Fund and National Research Council of Thailand, grant number DBG6180029 (C.M.).

Conflicts of Interest: The authors declare no conflict of interest.

\section{References}

1. Tsurkan, M.V.; Voronkina, A.; Khrunyk, Y.; Wysokowski, M.; Petrenko, I.; Ehrlich, H. Progress in chitin analytics. Carbohydr. Polym. 2020, 252, 117204. [CrossRef] [PubMed]

2. Wysokowski, M.; Machalowski, T.; Petrenko, I.; Schimpf, C.; Rafaja, D.; Galli, R.; Zietek, J.; Pantovic, S.; Voronkina, A.; Kovalchuk, V.; et al. 3D Chitin Scaffolds of Marine Demosponge Origin for Biomimetic Mollusk Hemolymph-Associated Biomineralization Ex-Vivo. Mar. Drugs 2020, 18, 123. [CrossRef] [PubMed]

3. Tsurkan, D.; Wysokowski, M.; Petrenko, I.; Voronkina, A.; Khrunyk, Y.; Fursov, A.; Ehrlich, H. Modern scaffolding strategies based on naturally pre-fabricated 3D biomaterials of poriferan origin. Appl. Phys. A 2020, 126, 382. [CrossRef]

4. Mutsenko, V.V.; Gryshkov, O.; Lauterboeck, L.; Rogulska, O.; Tarusin, D.N.; Bazhenov, V.V.; Schutz, K.; Bruggemeier, S.; Gossla, E.; Akkineni, A.R.; et al. Novel chitin scaffolds derived from marine sponge Ianthella basta for tissue engineering approaches based on human mesenchymal stromal cells: Biocompatibility and cryopreservation. Int. J. Biol. Macromol. 2017, 104, 1955-1965. [CrossRef] 
5. Petrenko, I.; Khrunyk, Y.; Voronkina, A.; Kovalchuk, V.; Fursov, A.; Tsurkan, D.; Ivanenko, V. Poriferan chitin: 3D scaffolds from nano-to macroscale. A review. Lett. Appl. Nanobiosci. 2020, 9, 1004-1014.

6. Machałowski, T.; Wysokowski, M.; Petrenko, I.; Fursov, A.; Rahimi-Nasrabadi, M.; Amro, M.d.M.; Meissner, H.; Joseph, Y.; Fazilov, B.; Ehrlich, H.; et al. Naturally pre-designed biomaterials: Spider molting cuticle as a functional crude oil sorbent. J. Environ. Manag. 2020, 261, 110218. [CrossRef] [PubMed]

7. Machałowski, T.; Amemiya, C.; Jesionowski, T. Chitin of Araneae origin: Structural features and biomimetic applications: A review. Appl. Phys. A 2020, 126, 1-17. [CrossRef]

8. Khrunyk, Y.; Lach, S.; Petrenko, I.; Ehrlich, H. Progress in Modern Marine Biomaterials Research. Mar. Drugs 2020, 18, 589. [CrossRef]

9. Wysokowski, M.; Petrenko, I.; Stelling, A.L.; Stawski, D.; Jesionowski, T.; Ehrlich, H. Poriferan chitin as a versatile template for extreme biomimetics. Polymers 2015, 7, 235-265. [CrossRef]

10. Petrenko, I.; Bazhenov, V.V.; Galli, R.; Wysokowski, M.; Fromont, J.; Schupp, P.J.; Stelling, A.L.; Niederschlag, E.; Stöker, H.; Kutsova, V.Z.; et al. Chitin of poriferan origin and the bioelectrometallurgy of copper/copper oxide. Int. J. Biol. Macromol. 2017, 104, 1626-1632. [CrossRef]

11. Moussian, B. Chitin: Structure, Chemistry and Biology. Adv. Exp. Med. Biol. 2019, 1142, 5-18. [CrossRef] [PubMed]

12. Kumar, P.T.S.; Srinivasan, S.; Lakshmanan, V.K.; Tamura, H.; Nair, S.V.; Jayakumar, R. Synthesis, characterization and cytocompatibility studies of $\alpha$-chitin hydrogel/nano hydroxyapatite composite scaffolds. Int. J. Biol. Macromol. 2011, 49, 20-31. [CrossRef] [PubMed]

13. Jayakumar, R.; Divya Rani, V.V.; Shalumon, K.T.; Kumar, P.T.S.; Nair, S.V.; Furuike, T.; Tamura, H. Bioactive and osteoblast cell attachment studies of novel $\alpha$ - and $\beta$-chitin membranes for tissue-engineering applications. Int. J. Biol. Macromol. 2009, 45, 260-264. [CrossRef] [PubMed]

14. Song, S.; Zhao, Y.; Yuan, X.; Zhang, J. $\beta$-Chitin nanofiber hydrogel as a scaffold to in situ fabricate monodispersed ultra-small silver nanoparticles. Colloids Surf. A 2019, 574, 36-43. [CrossRef]

15. Jung, H.S.; Kim, M.H.; Shin, J.Y.; Park, S.R.; Jung, J.Y.; Park, W.H. Electrospinning and wound healing activity of $\beta$-chitin extracted from cuttlefish bone. Carbohydr. Polym. 2018, 193, 205-211. [CrossRef]

16. Mulongo-Masamba, R.; El Hazzat, M.; El Hamidi, A.; Halim, M.; Arsalane, S. New functional $\beta$-chitin/calcium phosphate as promising support of copper nanocatalyst for the reductive degradation of methylene blue. Int. J. Environ. Sci. Technol. 2019, 16, 8117-8128. [CrossRef]

17. Somsak, P.; Sriwattana, S.; Prinyawiwatkul, W. Ultrasonic-assisted chitin nanoparticle and its application as saltiness enhancer. Int. J. Food Sci. Technol. 2020. [CrossRef]

18. Kaya, M.; Mujtaba, M.; Ehrlich, H.; Salaberria, A.M.; Baran, T.; Amemiya, C.T.; Galli, R.; Akyuz, L.; Sargin, I.; Labidi, J. On chemistry of $\gamma$-chitin. Carbohydr. Polym. 2017, 176, 177-186. [CrossRef]

19. Qin, Z.; Zhao, L. The History of Chito/Chitin Oligosaccharides and Its Monomer. In Oligosaccharides of Chitin and Chitosan: Bio-manufacture and Applications; Zhao, L., Ed.; Springer: Singapore, 2019; pp. 3-14.

20. Li, J.; Cai, C.; Li, J.; Li, J.; Li, J.; Sun, T.; Wang, L.; Wu, H.; Yu, G. Chitosan-Based Nanomaterials for Drug Delivery. Molecules 2018, 23, 2661. [CrossRef]

21. Jiang, T.; James, R.; Kumbar, S.G.; Laurencin, C.T. Chitosan as a Biomaterial: Structure, Properties, and Applications in Tissue Engineering and Drug Delivery. In Natural and Synthetic Biomedical Polymers; Kumbar, S.G., Laurencin, C.T., Deng, M., Eds.; Elsevier: Oxford, UK, 2014; pp. 91-113.

22. Muanprasat, C.; Chatsudthipong, V. Chitosan oligosaccharide: Biological activities and potential therapeutic applications. Pharmacol. Ther. 2017, 170, 80-97. [CrossRef]

23. Gallo, M.; Naviglio, D.; Armone Caruso, A.; Ferrara, L. Applications of chitosan as a functional food. In Novel Approaches of Nanotechnology in Food; Grumezescu, A.M., Ed.; Academic Press: London, UK, 2016; pp. 425-464.

24. Kim, S.H.; Eom, S.H.; Yu, D.; Lee, M.S.; Kim, Y.M. Oligochitosan as a potential anti-acne vulgaris agent: Combined antibacterial effects against Propionibacterium acnes. Food Sci. Biotechnol. 2017, 26, 1029-1036. [CrossRef] [PubMed]

25. Singh, N.; Chen, J.; Koziol, K.K.; Hallam, K.R.; Janas, D.; Patil, A.J.; Strachan, A.; Hanley, J.G.; Rahatekar, S.S. Chitin and carbon nanotube composites as biocompatible scaffolds for neuron growth. Nanoscale 2016, 8 , 8288-8299. [CrossRef] [PubMed]

26. Wang, Z.Y.; Wang, J.W.; Qin, L.H.; Zhang, W.G.; Zhang, P.X.; Jiang, B.G. Chitin biological absorbable catheters bridging sural nerve grafts transplanted into sciatic nerve defects promote nerve regeneration. CNS Neurosci. Ther. 2018, 24, 483-494. [CrossRef] [PubMed] 
27. Wang, Z.; Fan, J.; Yang, X.; Zhang, W.; Zhang, P.; Jiang, B. The neural regeneration effect of chitin biological absorbable tubes bridging sciatic nerve defects with sural nerve grafts. Am. J. Transl. Res. 2018, 10, 2362-2371. [PubMed]

28. Ji, X.; Lei, Z.; Yuan, M.; Zhu, H.; Yuan, X.; Liu, W.; Pu, H.; Jiang, J.; Zhang, Y.; Jiang, X.; et al. Cartilage repair mediated by thermosensitive photocrosslinkable TGF $\beta 1$-loaded GM-HPCH via immunomodulating macrophages, recruiting MSCs and promoting chondrogenesis. Theranostics 2020, 10, 2872-2887. [CrossRef]

29. Lin, H.L.; Wu, T.H.; Ho, H.O.; Chao, F.C.; Meng, H.; Liu, W.D.Z.; Chen, L.C.; Sheu, M.T. TEMPO-oxidized sacchachitin nanofibers (TOSCNFs) combined with platelet-rich plasma (PRP) for management of dry eye syndrome. Int. J. Nanomed. 2020, 15, 1721-1730. [CrossRef]

30. Lomiguen, C.; Vidal, L.; Kozlowski, P.; Prancan, A.; Stern, R. Possible role of chitin-like proteins in the etiology of Alzheimer's disease. J. Alzheimer's Dis. 2018, 66, 439-444. [CrossRef]

31. Castellani, R.J.; Perry, G.; Smith, M.A. The role of novel chitin-like polysaccharides in Alzheimer disease. Neurotox. Res. 2007, 12, 269-274. [CrossRef]

32. Castellani, R.J.; Siedlak, S.L.; Fortino, A.E.; Perry, G.; Ghetti, B.; Smith, M.A. Chitin-like polysaccharides in Alzheimer's disease brains. Curr. Alzheimer. Res. 2005, 2, 419-423. [CrossRef]

33. Pisa, D.; Alonso, R.; Rábano, A.; Horst, M.N.; Carrasco, L. Fungal enolase, $\beta$-tubulin, and chitin are detected in brain tissue from Alzheimer's disease patients. Front. Microbiol. 2016, 7. [CrossRef]

34. Sotgiu, S.; Musumeci, S.; Marconi, S.; Gini, B.; Bonetti, B. Different content of chitin-like polysaccharides in multiple sclerosis and Alzheimer's disease brains. J. Neuroimmunol. 2008, 197, 70-73. [CrossRef] [PubMed]

35. Turano, E.; Busetto, G.; Marconi, S.; Guzzo, F.; Farinazzo, A.; Commisso, M.; Bistaffa, E.; Angiari, S.; Musumeci, S.; Sotgiu, S.; et al. Neurotoxicity and synaptic plasticity impairment of $N$-acetylglucosamine polymers: Implications for Alzheimer's disease. Neurobiol. Aging 2015, 36, 1780-1791. [CrossRef] [PubMed]

36. Mutsenko, V.V.; Bazhenov, V.V.; Rogulska, O.; Tarusin, D.N.; Schütz, K.; Brüggemeier, S.; Gossla, E.; Akkineni, A.R.; Meißner, H.; Lode, A.; et al. 3D chitinous scaffolds derived from cultivated marine demosponge Aplysina aerophoba for tissue engineering approaches based on human mesenchymal stromal cells. Int. J. Biol. Macromol. 2017, 104, 1966-1974. [CrossRef] [PubMed]

37. Kim, M.S.; Sung, M.J.; Seo, S.B.; Yoo, S.J.; Lim, W.K.; Kim, H.M. Water-soluble chitosan inhibits the production of pro-inflammatory cytokine in human astrocytoma cells activated by amyloid beta peptide and interleukin-1beta. Neurosci. Lett. 2002, 321, 105-109. [CrossRef]

38. Lee, S.H.; Park, J.S.; Kim, S.K.; Ahn, C.B.; Je, J.Y. Chitooligosaccharides suppress the level of protein expression and acetylcholinesterase activity induced by A $325-35$ in PC12 cells. Bioorganic Med. Chem. Lett. 2009, 19, 860-862. [CrossRef]

39. Eom, T.K.; Ryu, B.; Lee, J.K.; Byun, H.G.; Park, S.J.; Kim, S.K. $\beta$-secretase inhibitory activity of phenolic acid conjugated chitooligosaccharides. J. Enzym. Inhib. Med. Chem. 2013, 28, 214-217. [CrossRef]

40. Dai, X.; Chang, P.; Li, X.; Gao, Z.; Sun, Y. The inhibitory effect of chitosan oligosaccharides on beta-site amyloid precursor protein cleaving enzyme 1 (BACE1) in HEK293 APPswe cells. Neurosci. Lett. 2018, 665, 80-85. [CrossRef]

41. Dai, X.; Hou, W.; Sun, Y.; Gao, Z.; Zhu, S.; Jiang, Z. Chitosan oligosaccharides inhibit/disaggregate fibrils and attenuate amyloid $\beta$-mediated neurotoxicity. Int. J. Mol. Sci. 2015, 16, 10526-10536. [CrossRef]

42. Hou, H.; Zhang, L.; Ye, Z.; Li, J.; Lian, Z.; Chen, C.; He, R.; Peng, B.; Xu, Q.; Zhang, G.; et al. Chitooligosaccharide Inhibits Scar Formation and Enhances Functional Recovery in a Mouse Model of Sciatic Nerve Injury. Mol. Neurobiol. 2016, 53, 2249-2257. [CrossRef]

43. Kunanusornchai, W.; Witoonpanich, B.; Tawonsawatruk, T.; Pichyangkura, R.; Chatsudthipong, V.; Muanprasat, C. Chitosan oligosaccharide suppresses synovial inflammation via AMPK activation: An in vitro and in vivo study. Pharm. Res. 2016, 113, 458-467. [CrossRef]

44. Jia, S.; Lu, Z.; Gao, Z.; An, J.; Wu, X.; Li, X.; Dai, X.; Zheng, Q.; Sun, Y. Chitosan oligosaccharides alleviate cognitive deficits in an amyloid-beta1-42-induced rat model of Alzheimer's disease. Int. J. Biol. Macromol. 2016, 83, 416-425. [CrossRef] [PubMed]

45. Dai, X.; Chang, P.; Zhu, Q.; Liu, W.; Sun, Y.; Zhu, S.; Jiang, Z. Chitosan oligosaccharides protect rat primary hippocampal neurons from oligomeric beta-amyloid 1-42-induced neurotoxicity. Neurosci. Lett. 2013, 554, 64-69. [CrossRef] [PubMed] 
46. Inui, H.; Tsujikubo, M.; Hirano, S. Low molecular weight chitosan stimulation of mitogenic response to platelet-derived growth factor in vascular smooth muscle cells. Biosci. Biotechnol. Biochem. 1995, 59, 2111-2114. [CrossRef]

47. Chien, Y.; Liao, Y.W.; Liu, D.M.; Lin,H.L.; Chen, S.J.; Chen, H.L.; Peng, C.H.; Liang, C.M.; Mou, C.Y.; Chiou, S.H. Corneal repair by human corneal keratocyte-reprogrammed iPSCs and amphiphatic carboxymethyl-hexanoyl chitosan hydrogel. Biomaterials 2012, 33, 8003-8016. [CrossRef] [PubMed]

48. Wu, H.; Liu, J.; Fang, Q.; Xiao, B.; Wan, Y. Establishment of nerve growth factor gradients on aligned chitosan-polylactide /alginate fibers for neural tissue engineering applications. Colloids Surf. B 2017, 160, 598-609. [CrossRef] [PubMed]

49. Wei, C.K.; Ding, S.J. Acid-resistant calcium silicate-based composite implants with high-strength as load-bearing bone graft substitutes and fracture fixation devices. J. Mech. Behav. Biomed. Mater. 2016, 62, 366-383. [CrossRef] [PubMed]

50. Jaruszewski, K.M.; Ramakrishnan, S.; Poduslo, J.F.; Kandimalla, K.K. Chitosan enhances the stability and targeting of immuno-nanovehicles to cerebro-vascular deposits of Alzheimer's disease amyloid protein. Nanomedicine 2012, 8, 250-260. [CrossRef]

51. Mahl, C.R.A.; Taketa, T.B.; Rocha-Neto, J.B.M.; Almeida, W.P.; Beppu, M.M. Copper Ion Uptake by Chitosan in the Presence of Amyloid-beta and Histidine. Appl. Biochem. Biotechnol. 2020, 190, 949-965. [CrossRef]

52. Casadome-Perales, A.; Matteis, L.; Alleva, M.; Infantes-Rodriguez, C.; Palomares-Perez, I.; Saito, T.; Saido, T.C.; Esteban, J.A.; Nebreda, A.R.; de la Fuente, J.M.; et al. Inhibition of p38 MAPK in the brain through nasal administration of p38 inhibitor loaded in chitosan nanocapsules. Nanomedicine 2019, 14, 2409-2422. [CrossRef]

53. Kheradmandi, M.; Vasheghani-Farahani, E.; Ghiaseddin, A.; Ganji, F. Skeletal muscle regeneration via engineered tissue culture over electrospun nanofibrous chitosan/PVA scaffold. J. Biomed. Mater. Res. A 2016, 104, 1720-1727. [CrossRef]

54. Li, Y.; Yu, Z.; Men, Y.; Chen, X.; Wang, B. Laminin-chitosan-PLGA conduit co-transplanted with Schwann and neural stem cells to repair the injured recurrent laryngeal nerve. Exp. Med. 2018, 16, 1250-1258. [CrossRef] [PubMed]

55. Liu, H.; Huang, H.; Bi, W.; Tan, X.; Li, R.; Wen, W.; Song, W.; Zhang, Y.; Zhang, F.; Hu, M. Effect of chitosan combined with hyaluronate on promoting the recovery of postoperative facial nerve regeneration and function in rabbits. Exp. Med. 2018, 16, 739-745. [CrossRef] [PubMed]

56. Crosio, A.; Fornasari, B.E.; Gambarotta, G.; Geuna, S.; Raimondo, S.; Battiston, B.; Tos, P.; Ronchi, G. Chitosan tubes enriched with fresh skeletal muscle fibers for delayed repair of peripheral nerve defects. Neural. Regen. Res. 2019, 14, 1079-1084. [CrossRef] [PubMed]

57. Carvalho, C.R.; Costa, J.B.; Costa, L.; Silva-Correia, J.; Moay, Z.K.; Ng, K.W.; Reis, R.L.; Oliveira, J.M. Enhanced performance of chitosan/keratin membranes with potential application in peripheral nerve repair. Biomater. Sci. 2019, 7, 5451-5466. [CrossRef]

58. Moattari, M.; Kouchesfehani, H.M.; Kaka, G.; Sadraie, S.H.; Naghdi, M.; Mansouri, K. Chitosan-film associated with mesenchymal stem cells enhanced regeneration of peripheral nerves: A rat sciatic nerve model. J. Chem. Neuroanat. 2018, 88, 46-54. [CrossRef]

59. Neyrinck, A.M.; Catry, E.; Taminiau, B.; Cani, P.D.; Bindels, L.B.; Daube, G.; Dessy, C.; Delzenne, N.M. Chitin-glucan and pomegranate polyphenols improve endothelial dysfunction. Sci. Rep. 2019, 9, 14150. [CrossRef]

60. Song, X.; Huang, X.; Li, Z.; Li, Z.; Wu, K.; Jiao, Y.; Zhou, C. Construction of blood compatible chitin/graphene oxide composite aerogel beads for the adsorption of bilirubin. Carbohydr. Polym. 2019, 207, 704-712. [CrossRef]

61. Zhang, J.; Xue, S.; Zhu, X.; Zhao, Y.; Chen, Y.; Tong, J.; Shi, X.; Du, Y.; Zhong, Z.; Ye, Q. Emerging chitin nanogels/rectorite nanocomposites for safe and effective hemorrhage control. J. Mater. Chem. B 2019, 7, 5096-5103. [CrossRef]

62. Schubert, M.; Binnewerg, B.; Voronkina, A.; Muzychka, L.; Wysokowski, M.; Petrenko, I.; Kovalchuk, V.; Tsurkan, M.; Martinovic, R.; Bechmann, N.; et al. Naturally Prefabricated Marine Biomaterials: Isolation and Applications of Flat Chitinous 3D Scaffolds from Ianthella labyrinthus (Demospongiae: Verongiida). Int. J. Mol. Sci. 2019, 20, 5105. [CrossRef]

63. Machałowski, T.; Wysokowski, M.; Żółtowska-Aksamitowska, S.; Bechmann, N.; Binnewerg, B.; Schubert, M.; Guan, K.; Bornstein, S.R.; Czaczyk, K.; Pokrovsky, O.; et al. Spider Chitin. The biomimetic potential and applications of Caribena versicolor tubular chitin. Carbohydr. Polym. 2019, 226, 115301. [CrossRef] 
64. Ormrod, D.J.; Holmes, C.C.; Miller, T.E. Dietary chitosan inhibits hypercholesterolaemia and atherogenesis in the apolipoprotein E-deficient mouse model of atherosclerosis. Atherosclerosis 1998, 138, 329-334. [CrossRef]

65. Bahijri, S.M.; Alsheikh, L.; Ajabnoor, G.; Borai, A. Effect of Supplementation With Chitosan on Weight, Cardiometabolic, and Other Risk Indices in Wistar Rats Fed Normal and High-Fat/High-Cholesterol Diets Ad Libitum. Nutr. Metab. Insights 2017, 10, 1178638817710666. [CrossRef] [PubMed]

66. Zong, C.; Yu, Y.; Song, G.; Luo, T.; Li, L.; Wang, X.; Qin, S. Chitosan oligosaccharides promote reverse cholesterol transport and expression of scavenger receptor BI and CYP7A1 in mice. Exp. Biol. Med. (Maywood) 2012, 237, 194-200. [CrossRef] [PubMed]

67. Yang, X.; Zhang, J.; Chen, L.; Wu, Q.; Yu, C. Chitosan oligosaccharides enhance lipid droplets via down-regulation of PCSK9 gene expression in HepG2 cells. Exp. Cell. Res. 2018, 366, 152-160. [CrossRef]

68. Li, Y.; Xu, Q.; Wei, P.; Cheng, L.; Peng, Q.; Li, S.; Yin, H.; Du, Y. Chitosan oligosaccharides downregulate the expression of E-selectin and ICAM-1 induced by LPS in endothelial cells by inhibiting MAP kinase signaling. Int. J. Mol. Med. 2014, 33, 392-400. [CrossRef]

69. Yu, Y.; Luo, T.; Liu, S.; Song, G.; Han, J.; Wang, Y.; Yao, S.; Feng, L.; Qin, S. Chitosan Oligosaccharides Attenuate Atherosclerosis and Decrease Non-HDL in ApoE-/- Mice. J. Atheroscler. Thromb. 2015, 22, 926-941. [CrossRef]

70. Xiong, Y.; Xiong, M.; Li, Y.; Qian, J.; Li, Y.; Han, X.; Tan, J.; Luo, Y.; Wang, Q.; Qin, C. Chitosan oligosaccharide combined with running benefited the immune status of rats. Int. Immunopharmacol. 2020, 88, 106915. [CrossRef]

71. Zhu, L.; Hu, B.; Guo, Y.; Yang, H.; Zheng, J.; Yao, X.; Hu, H.; Liu, H. Effect of Chitosan oligosaccharides on ischemic symptom and gut microbiota disbalance in mice with hindlimb ischemia. Carbohydr. Polym. 2020, 240, 116271. [CrossRef]

72. Termsarasab, U.; Yoon, I.S.; Park, J.H.; Moon, H.T.; Cho, H.J.; Kim, D.D. Polyethylene glycol-modified arachidyl chitosan-based nanoparticles for prolonged blood circulation of doxorubicin. Int. J. Pharm. 2014, 464, 127-134. [CrossRef]

73. Yu, J.; Ruan, Q.; Nie, X.; Yu, L.; Huang, B. Synthetic CD47 antibody-chitosan/hyaluronic acid polyelectrolyte complex mediates targeted inhibition of atherosclerotic plaques by exogenous foam-like cells via the NLRP3 pathway. J. Biomater. Appl. 2020, 34, 1381-1394. [CrossRef]

74. Tang, H.; Fang, Z.; Sun, Y.; Li, B.; Shi, Z.; Chen, J.; Zhang, T.; Xiu, Q. YKL-40 in asthmatic patients, and its correlations with exacerbation, eosinophils and immunoglobulin E. Eur. Respir. J. 2010, 35, 757-760. [CrossRef] [PubMed]

75. Liu, L.; Zhang, X.; Liu, Y.; Zhang, L.; Zheng, J.; Wang, J.; Hansbro, P.M.; Wang, L.; Wang, G.; Hsu, A.C.Y. Chitinase-like protein YKL-40 correlates with inflammatory phenotypes, anti-asthma responsiveness and future exacerbations. Respir. Res. 2019, 20, 95. [CrossRef] [PubMed]

76. Van Dyken, S.J.; Garcia, D.; Porter, P.; Huang, X.; Quinlan, P.J.; Blanc, P.D.; Corry, D.B.; Locksley, R.M. Fungal chitin from asthma-associated home environments induces eosinophilic lung infiltration. J. Immunol. 2011, 187, 2261-2267. [CrossRef] [PubMed]

77. Khosravi, A.R.; Erle, D.J. Chitin-Induced Airway Epithelial Cell Innate Immune Responses Are Inhibited by Carvacrol/Thymol. PLoS ONE 2016, 11, e0159459. [CrossRef]

78. Choi, J.P.; Lee, S.M.; Choi, H.I.; Kim, M.H.; Jeon, S.G.; Jang, M.H.; Jee, Y.K.; Yang, S.; Cho, Y.J.; Kim, Y.K. House Dust Mite-Derived Chitin Enhances Th2 Cell Response to Inhaled Allergens, Mainly via a TNF-alpha-Dependent Pathway. Allergy Asthma Immunol. Res. 2016, 8, 362-374. [CrossRef]

79. Boot, R.G.; Renkema, G.H.; Strijland, A.; van Zonneveld, A.J.; Aerts, J.M. Cloning of a cDNA encoding chitotriosidase, a human chitinase produced by macrophages. J. Biol. Chem. 1995, 270, 26252-26256. [CrossRef]

80. Cho, S.J.; Weiden, M.D.; Lee, C.G. Chitotriosidase in the pathogenesis of inflammation, interstitial lung diseases and COPD. Allergy Asthma Immunol. Res. 2014, 7, 14-21. [CrossRef]

81. Garth, J.M.; Mackel, J.J.; Reeder, K.M.; Blackburn, J.P.; Dunaway, C.W.; Yu, Z.; Matalon, S.; Fitz, L.; Steele, C. Acidic Mammalian Chitinase Negatively Affects Immune Responses during Acute and Chronic Aspergillus fumigatus Exposure. Infect. Immun. 2018, 86. [CrossRef]

82. Mazur, M.; Dymek, B.; Koralewski, R.; Sklepkiewicz, P.; Olejniczak, S.; Mazurkiewicz, M.; Piotrowicz, M.; Salamon, M.; Jȩdrzejczak, K.; Zagozdzon, A.; et al. Development of Dual Chitinase Inhibitors as Potential New Treatment for Respiratory System Diseases. J. Med. Chem. 2019, 62, 7126-7145. [CrossRef] 
83. Das, P.; Acharya, S.; Shah, D.; Agarwal, B.; Prahaladan, V.; Bhandari, V. Chitin Analog AVR-25 Prevents Experimental Bronchopulmonary Dysplasia. J. Pediatr. Intensive Care 2020, 9, 225-232. [CrossRef]

84. Zhao, Y.; Xu, G.; Wang, S.; Yi, X.; Wu, W. Chitosan oligosaccharides alleviate PM2.5-induced lung inflammation in rats. Environ. Sci. Pollut. Res. Int. 2018, 25, 34221-34227. [CrossRef] [PubMed]

85. Liu, Y.E.; Tong, C.C.; Zhang, Y.B.; Cong, P.F.; Shi, X.Y.; Liu, Y.; Shi, L.; Tong, Z.; Jin, H.X.; Hou, M.X. Chitosan oligosaccharide ameliorates acute lung injury induced by blast injury through the DDAH1/ADMA pathway. PLOS ONE 2018, 13, e0192135. [CrossRef] [PubMed]

86. Chung, M.J.; Park, J.K.; Park, Y.I. Anti-inflammatory effects of low-molecular weight chitosan oligosaccharides in IgE-antigen complex-stimulated RBL-2H3 cells and asthma model mice. Int. Immunopharmacol. 2012, 12, 453-459. [CrossRef] [PubMed]

87. Anraku, M.; Tabuchi, R.; Ifuku, S.; Nagae, T.; Iohara, D.; Tomida, H.; Uekama, K.; Maruyama, T.; Miyamura, S.; Hirayama, F.; et al. An oral absorbent, surface-deacetylated chitin nano-fiber ameliorates renal injury and oxidative stress in 5/6 nephrectomized rats. Carbohydr. Polym. 2017, 161, 21-25. [CrossRef] [PubMed]

88. Conroy, A.L.; Hawkes, M.T.; Elphinstone, R.; Opoka, R.O.; Namasopo, S.; Miller, C.; John, C.C.; Kain, K.C. Chitinase-3-like 1 is a biomarker of acute kidney injury and mortality in paediatric severe malaria. Malar. J. 2018, 17, 82. [CrossRef]

89. Schmidt, I.M.; Hall, I.E.; Kale, S.; Lee, S.; He, C.-H.; Lee, Y.; Chupp, G.L.; Moeckel, G.W.; Lee, C.G.; Elias, J.A.; et al. Chitinase-Like Protein Brp-39/YKL-40 Modulates the Renal Response to Ischemic Injury and Predicts Delayed Allograft Function. J. Am. Soc. Nephrol. 2013, 24, 309. [CrossRef]

90. Bai, W.; Wang, S.; An, S.; Guo, M.; Gong, G.; Liu, W.; Ma, S.; Li, X.; Fu, J.; Yao, W. Combination therapy of chitosan, gynostemma, and motherwort alleviates the progression of experimental rat chronic renal failure by inhibiting STAT1 activation. Oncotarget 2018, 9, 15498-15511. [CrossRef]

91. Queiroz, M.F.; Melo, K.R.T.; Sabry, D.A.; Sassaki, G.L.; Rocha, H.A.O.; Costa, L.S. Gallic Acid-Chitosan Conjugate Inhibits the Formation of Calcium Oxalate Crystals. Molecules 2019, 24. [CrossRef]

92. Biasibetti, E.; Martello, E.; Bigliati, M.; Biasato, I.; Cocca, T.; Bruni, N.; Capucchio, M.T. A long term feed supplementation based on phosphate binders in Feline Chronic Kidney Disease. Vet. Res. Commun. 2018, 42, 161-167. [CrossRef]

93. Liu, B.; Qin, Z.K.; Lin, X.M.; Mei, L.; Liu, W.S.; Han, B.Q. Effects of chitooligosaccharides and its derivatives on antioxygenization and renal function in experimental diabetes rats. J. Clin. Rehabil. Tissue Eng. Res. 2008, $12,9651-9654$.

94. Yoon, H.J.; Moon, M.E.; Park, H.S.; Kim, H.W.; Im, S.Y.; Lee, J.H.; Kim, Y.H. Effects of chitosan oligosaccharide (COS) on the glycerol-induced acute renal failure in vitro and in vivo. Food Chem. Toxicol. 2008, 46, 710-716. [CrossRef] [PubMed]

95. Qiao, J.; Liu, Y.; Jiang, Z.; Yang, Y.; Liu, W.; Han, B. Preparation and renoprotective effects of carboxymethyl chitosan oligosaccharide on adriamycin nephropathy. Carbohydr. Polym. 2018, 201, 347-356. [CrossRef] [PubMed]

96. Zhai, X.; Yuan, S.; Yang, X.; Zou, P.; Li, L.; Li, G.; Shao, Y.; Abd El-Aty, A.M.; Hacimuftuoglu, A.; Wang, J. Chitosan Oligosaccharides Induce Apoptosis in Human Renal Carcinoma via Reactive-OxygenSpecies-Dependent Endoplasmic Reticulum Stress. J. Agric. Food Chem. 2019, 67, 1691-1701. [CrossRef] [PubMed]

97. Zhang, X.F.; Ding, C.L.; Liu, H.; Liu, L.H.; Zhao, C.Q. Protective effects of ion-imprinted chitooligosaccharides as uranium-specific chelating agents against the cytotoxicity of depleted uranium in human kidney cells. Toxicology 2011, 286, 75-84. [CrossRef]

98. Pathomthongtaweechai, N.; Soodvilai, S.; Pichyangkura, R.; Muanprasat, C. Novel Potential Application of Chitosan Oligosaccharide for Attenuation of Renal Cyst Growth in the Treatment of Polycystic Kidney Disease. Molecules 2020, 25, 5589. [CrossRef]

99. Anraku, M.; Tanaka, M.; Hiraga, A.; Nagumo, K.; Imafuku, T.; Maezaki, Y.; Iohara, D.; Uekama, K.; Watanabe, H.; Hirayama, F.; et al. Effects of chitosan on oxidative stress and related factors in hemodialysis patients. Carbohydr. Polym. 2014, 112, 152-157. [CrossRef]

100. Salva, E.; Turan, S.O.; Akbuga, J. Inhibition of Glomerular Mesangial Cell Proliferation by siPDGF-B- and siPDGFR-beta-Containing Chitosan Nanoplexes. AAPS PharmSciTech. 2017, 18, 1031-1042. [CrossRef]

101. Chiang, I.N.; Huang, W.C.; Huang, C.Y.; Pu, Y.S.; Young, T.H. Development of a chitosan-based tissue-engineered renal proximal tubule conduit. J. Biomed. Mater. Res. B 2018, 106, 9-20. [CrossRef] 
102. Sutthasupha, P.; Lungkaphin, A. The potential roles of chitosan oligosaccharide in prevention of kidney injury in obese and diabetic conditions. Food Funct. 2020, 11, 7371-7388. [CrossRef]

103. Liberti, A.; Zucchetti, I.; Melillo, D.; Skapura, D.; Shibata, Y.; De Santis, R.; Pinto, M.R.; Litman, G.W.; Dishaw, L.J. Chitin protects the gut epithelial barrier in a protochordate model of DSS-induced colitis. Biol. Open 2018, 7. [CrossRef]

104. Alessandri, G.; Milani, C.; Duranti, S.; Mancabelli, L.; Ranjanoro, T.; Modica, S.; Carnevali, L.; Statello, R.; Bottacini, F.; Turroni, F.; et al. Ability of bifidobacteria to metabolize chitin-glucan and its impact on the gut microbiota. Sci. Rep. 2019, 9, 5755. [CrossRef] [PubMed]

105. Rodriguez, J.; Neyrinck, A.M.; Zhang, Z.; Seethaler, B.; Nazare, J.A.; Robles Sanchez, C.; Roumain, M.; Muccioli, G.G.; Bindels, L.B.; Cani, P.D.; et al. Metabolite profiling reveals the interaction of chitin-glucan with the gut microbiota. Gut. Microbes 2020, 12, 1810530. [CrossRef] [PubMed]

106. Goto, M.; Iohara, D.; Michihara, A.; Ifuku, S.; Azuma, K.; Kadowaki, D.; Maruyama, T.; Otagiri, M.; Hirayama, F.; Anraku, M. Effects of surface-deacetylated chitin nanofibers on non-alcoholic steatohepatitis model rats and their gut microbiota. Int. J. Biol. Macromol. 2020, 164, 659-666. [CrossRef] [PubMed]

107. Liu, P.; Piao, X.S.; Thacker, P.A.; Zeng, Z.K.; Li, P.F.; Wang, D.; Kim, S.W. Chito-oligosaccharide reduces diarrhea incidence and attenuates the immune response of weaned pigs challenged with Escherichia coli K88. J. Anim. Sci. 2010, 88, 3871-3879. [CrossRef] [PubMed]

108. Liu, P.; Piao, X.S.; Kim, S.W.; Wang, L.; Shen, Y.B.; Lee, H.S.; Li, S.Y. Effects of chito-oligosaccharide supplementation on the growth performance, nutrient digestibility, intestinal morphology, and fecal shedding of Escherichia coli and Lactobacillus in weaning pigs. J. Anim. Sci. 2008, 86, 2609-2618. [CrossRef] [PubMed]

109. Qian, L.; Yue, X.; Hu, L.; Ma, Y.; Han, X. Changes in diarrhea, nutrients apparent digestibility, digestive enzyme activities of weaned piglets in response to chitosan-zinc chelate. Anim. Sci. J. 2016, 87, 564-569. [CrossRef] [PubMed]

110. Aluko, K.; Velayudhan, D.E.; Khafipour, E.; Li, A.; Yin, Y.; Nyachoti, M. Combined effects of chitosan and microencapsulated Enterococcus faecalis CG1.0007 probiotic supplementation on performance and diarrhea incidences in enterotoxigenic Escherichia coli K88(+) challenged piglets. Anim. Nutr. 2017, 3, 366-371. [CrossRef]

111. Hu, S.; Wang, Y.; Wen, X.; Wang, L.; Jiang, Z.; Zheng, C. Effects of low-molecular-weight chitosan on the growth performance, intestinal morphology, barrier function, cytokine expression and antioxidant system of weaned piglets. Bmc. Vet. Res. 2018, 14, 215. [CrossRef]

112. Thongsong, B.; Suthongsa, S.; Pichyangkura, R.; Kalandakanond-Thongsong, S. Effects of chito-oligosaccharide supplementation with low or medium molecular weight and high degree of deacetylation on growth performance, nutrient digestibility and small intestinal morphology in weaned pigs. Livest. Sci. 2018, 209, 60-66. [CrossRef]

113. Zheng, J.; Yuan, X.; Cheng, G.; Jiao, S.; Feng, C.; Zhao, X.; Yin, H.; Du, Y.; Liu, H. Chitosan oligosaccharides improve the disturbance in glucose metabolism and reverse the dysbiosis of gut microbiota in diabetic mice. Carbohydr. Polym. 2018, 190, 77-86. [CrossRef]

114. Muanprasat, C.; Wongkrasant, P.; Satitsri, S.; Moonwiriyakit, A.; Pongkorpsakol, P.; Mattaveewong, T.; Pichyangkura, R.; Chatsudthipong, V. Activation of AMPK by chitosan oligosaccharide in intestinal epithelial cells: Mechanism of action and potential applications in intestinal disorders. Biochem. Pharm. 2015, 96, 225-236. [CrossRef] [PubMed]

115. Bai, Y.; Zheng, J.; Yuan, X.; Jiao, S.; Feng, C.; Du, Y.; Liu, H.; Zheng, L. Chitosan oligosaccharides improve glucolipid metabolism disorder in liver by suppression of obesity-related inflammation and restoration of peroxisome proliferator-activated receptor gamma (PPAR $\gamma$ ). Mar. Drugs 2018, 16. [CrossRef] [PubMed]

116. Prajapati, B.; Rajput, P.; Jena, P.K.; Seshadri, S. Investigation of Chitosan for Prevention of Diabetic Progression Through Gut Microbiota Alteration in Sugar Rich Diet Induced Diabetic Rats. Curr. Pharm. Biotechnol. 2015, 17, 173-184. [CrossRef] [PubMed]

117. Mateos-Aparicio, I.; Mengibar, M.; Heras, A. Effect of chito-oligosaccharides over human faecal microbiota during fermentation in batch cultures. Carbohydr. Polym. 2016, 137, 617-624. [CrossRef] [PubMed]

118. Rowan, F.; Docherty, N.G.; Murphy, M.; Murphy, B.; Calvin Coffey, J.; O'Connell, P.R. Desulfovibrio bacterial species are increased in ulcerative colitis. Dis. Colon. Rectum. 2010, 53, 1530-1536. [CrossRef] [PubMed]

119. Zhang, C.; Jiao, S.; Wang, Z.A.; Du, Y. Exploring Effects of Chitosan Oligosaccharides on Mice Gut Microbiota in in vitro Fermentation and Animal Model. Front. Microbiol. 2018, 9, 2388. [CrossRef] 
120. Wu, M.; Li, J.; An, Y.; Li, P.; Xiong, W.; Li, J.; Yan, D.; Wang, M.; Zhong, G. Chitooligosaccharides Prevents the Development of Colitis-Associated Colorectal Cancer by Modulating the Intestinal Microbiota and Mycobiota. Front. Microbiol. 2019, 10, 2101. [CrossRef]

121. Qian, M.; Lyu, Q.; Liu, Y.; Hu, H.; Wang, S.; Pan, C.; Duan, X.; Gao, Y.; Qi, L.W.; Liu, W.; et al. Chitosan Oligosaccharide Ameliorates Nonalcoholic Fatty Liver Disease (NAFLD) in Diet-Induced Obese Mice. Mar. Drugs 2019, 17. [CrossRef]

122. Saleh, H.; El-Shorbagy, H.M. Chitosan protects liver against ischemia-reperfusion injury via regulating Bcl-2/Bax, TNF-alpha and TGF-beta expression. Int. J. Biol. Macromol. 2020, 164, 1565-1574. [CrossRef]

123. Tong, A.J.; Hu, R.K.; Wu, L.X.; Lv, X.C.; Li, X.; Zhao, L.N.; Liu, B. Ganoderma polysaccharide and chitosan synergistically ameliorate lipid metabolic disorders and modulate gut microbiota composition in high fat diet-fed golden hamsters. J. Food. Biochem. 2020, 44, e13109. [CrossRef]

124. Wu, X.; Kim, M.J.; Yang, H.J.; Park, S. Chitosan alleviated menopausal symptoms and modulated the gut microbiota in estrogen-deficient rats. Eur. J. Nutr. 2020, 1-13. [CrossRef] [PubMed]

125. Wang, J.; Kong, M.; Zhou, Z.; Yan, D.; Yu, X.; Cheng, X.; Feng, C.; Liu, Y.; Chen, X. Mechanism of surface charge triggered intestinal epithelial tight junction opening upon chitosan nanoparticles for insulin oral delivery. Carbohydr. Polym. 2017, 157, 596-602. [CrossRef] [PubMed]

126. Xu, Y.; Mao, H.; Yang, C.; Du, H.; Wang, H.; Tu, J. Effects of chitosan nanoparticle supplementation on growth performance, humoral immunity, gut microbiota and immune responses after lipopolysaccharide challenge in weaned pigs. J. Anim. Physiol. Anim. Nutr. (Berl) 2020, 104, 597-605. [CrossRef] [PubMed]

127. Nopvichai, C.; Pongkorpsakol, P.; Wongkrasant, P.; Wangpaiboon, K.; Charoenwongpaiboon, T.; Ito, K.; Muanprasat, C.; Pichyangkura, R. Galactomannan Pentasaccharide Produced from Copra Meal Enhances Tight Junction Integration of Epithelial Tissue through Activation of AMPK. Biomedicines 2019, 7. [CrossRef] [PubMed]

128. Nopvichai, C.; Charoenwongpaiboon, T.; Luengluepunya, N.; Ito, K.; Muanprasat, C.; Pichyangkura, R. Production and purification of mannan oligosaccharide with epithelial tight junction enhancing activity. PeerJ 2019, 7, e7206. [CrossRef] [PubMed]

129. Wongkrasant, P.; Pongkorpsakol, P.; Ariyadamrongkwan, J.; Meesomboon, R.; Satitsri, S.; Pichyangkura, R.; Barrett, K.E.; Muanprasat, C. A prebiotic fructo-oligosaccharide promotes tight junction assembly in intestinal epithelial cells via an AMPK-dependent pathway. Biomed. Pharm. 2020, 129, 110415. [CrossRef] [PubMed]

130. Bays, H.E.; Evans, J.L.; Maki, K.C.; Evans, M.; Maquet, V.; Cooper, R.; Anderson, J.W. Chitin-glucan fiber effects on oxidized low-density lipoprotein: A randomized controlled trial. Eur. J. Clin. Nutr. 2013, 67, 2-7. [CrossRef]

131. Yu, P.; Xie, J.; Chen, Y.; Liu, J.; Liu, Y.; Bi, B.; Luo, J.; Li, S.; Jiang, X.; Li, J. A thermo-sensitive injectable hydroxypropyl chitin hydrogel for sustained salmon calcitonin release with enhanced osteogenesis and hypocalcemic effects. J. Mater. Chem. B 2020, 8, 270-281. [CrossRef]

132. Xing, R.; He, X.; Liu, S.; Yu, H.; Qin, Y.; Chen, X.; Li, K.; Li, R.; Li, P. Antidiabetic activity of differently regioselective chitosan sulfates in alloxan-induced diabetic rats. Mar. Drugs 2015, 13, 3072-3090. [CrossRef]

133. Arun, G.; Rajaram, R.; Kaleshkumar, K.; Gayathri, N.; Sivasudha, T.; Kandasamy, S. Synergistic effect of novel chitosan combined metformin drug on streptozotocin-induced diabetes mellitus rat. Int. J. Biol. Macromol. 2020, 153, 1335-1349. [CrossRef]

134. Yan, H.; Rong, L.; Xiao, D.; Zhang, M.; Sheikh, S.P.; Sui, X.; Lu, M. Injectable and self-healing hydrogel as a stem cells carrier for treatment of diabetic erectile dysfunction. Mater. Sci. Eng. C 2020, 116, 111214. [CrossRef] [PubMed]

135. Wong, C.Y.; Al-Salami, H.; Dass, C.R. Lyophilisation Improves Bioactivity and Stability of Insulin-Loaded Polymeric-Oligonucleotide Nanoparticles for Diabetes Treatment. Aaps. Pharmscitech. 2020, 21, 108. [CrossRef]

136. Trinh, T.A.; Duy Le, T.M.; Ho, H.G.V.; To, T.C.T.; Nguyen, V.V.L.; Huynh, D.P.; Lee, D.S. A novel injectable $\mathrm{pH}$-temperature sensitive hydrogel containing chitosan-insulin electrosprayed nanosphere composite for an insulin delivery system in type I diabetes treatment. Biomater. Sci. 2020, 8, 3830-3843. [CrossRef] [PubMed]

137. Hashemi, A.; Ezati, M.; Mohammadnejad, J.; Houshmand, B.; Faghihi, S. Chitosan Coating of TiO2 Nanotube Arrays for Improved Metformin Release and Osteoblast Differentiation. Int. J. Nanomed. 2020, 15, 4471-4481. [CrossRef] [PubMed] 
138. Du, S.; Lv, Y.; Li, N.; Huang, X.; Liu, X.; Li, H.; Wang, C.; Jia, Y.F. Biological investigations on therapeutic effect of chitosan encapsulated nano resveratrol against gestational diabetes mellitus rats induced by streptozotocin. Drug Deliv. 2020, 27, 953-963. [CrossRef] [PubMed]

139. Bansal, A.; D'Sa, S.; D'Souza, M.J. Biofabrication of microcapsules encapsulating beta-TC-6 cells via scalable device and in-vivo evaluation in type 1 diabetic mice. Int. J. Pharm. 2019, 572, 118830. [CrossRef] [PubMed]

140. Al-Nemrawi, N.K.; Alsharif, S.S.M.; Alzoubi, K.H.; Alkhatib, R.Q. Preparation and characterization of insulin chitosan-nanoparticles loaded in buccal films. Pharm. Dev. Technol. 2019, 24, 967-974. [CrossRef]

141. Zeng, S.; Ke, Y.; Liu, Y.; Shen, Y.; Zhang, L.; Li, C.; Liu, A.; Shen, L.; Hu, X.; Wu, H.; et al. Synthesis and antidiabetic properties of chitosan-stabilized selenium nanoparticles. Colloids Surf. B 2018, 170, 115-121. [CrossRef]

142. Xu, J.; Cao, L.; Suo, Y.; Xu, X.; Sun, H.; Xu, S.; Zhu, X.; Yu, H.; Cao, W. Chitosan-microcapsulated insulin alleviates mesenteric microcirculation dysfunction via modulating COX-2 and VCAM-1 expression in rats with diabetes mellitus. Int. J. Nanomed. 2018, 13, 6829-6837. [CrossRef]

143. Kumar, S.G.; Rahman, M.A.; Lee, S.H.; Hwang, H.S.; Kim, H.A.; Yun, J.W. Plasma proteome analysis for anti-obesity and anti-diabetic potentials of chitosan oligosaccharides in ob/ob mice. Proteomics 2009, 9, 2149-2162. [CrossRef]

144. Liu, B.; Liu, W.S.; Han, B.Q.; Sun, Y.Y. Antidiabetic effects of chitooligosaccharides on pancreatic islet cells in streptozotocin-induced diabetic rats. World J. Gastroenterol. 2007, 13, 725-731. [CrossRef] [PubMed]

145. Liu, B.; Qin, Z.K.; Lin, X.M.; Mei, L.; Liu, W.S.; Han, B.Q. Antidiabetic effects of chitooligosaccharides with different molecular weights on pancreatic islet cells in streptozotocin-induced diabetic rats. World Chin. J. Dig. 2009, 17, 36-42. [CrossRef]

146. Qinna, N.A.; Karwi, Q.G.; Al-Jbour, N.; Al-Remawi, M.A.; Alhussainy, T.M.; Al-So'ud, K.A.; Al Omari, M.M.; Badwan, A.A. Influence of molecular weight and degree of deacetylation of low molecular weight chitosan on the bioactivity of oral insulin preparations. Mar. Drugs 2015, 13, 1710-1725. [CrossRef] [PubMed]

147. Kim, H.J.; Ahn, H.Y.; Kwak, J.H.; Shin, D.Y.; Kwon, Y.I.; Oh, C.G.; Lee, J.H. The effects of chitosan oligosaccharide (GO2KA1) supplementation on glucose control in subjects with prediabetes. Food Funct. 2014, 5, 2662-2669. [CrossRef] [PubMed]

148. Yu, S.Y.; Kwon, Y.I.; Lee, C.; Apostolidis, E.; Kim, Y.C. Antidiabetic effect of chitosan oligosaccharide (GO2KA1) is mediated via inhibition of intestinal alpha-glucosidase and glucose transporters and PPARgamma expression. BioFactors 2017, 43, 90-99. [CrossRef] [PubMed]

149. Jeong, S.; Min Cho, J.; Kwon, Y.I.; Kim, S.C.; Yeob Shin, D.; Ho Lee, J. Chitosan oligosaccharide (GO2KA1) improves postprandial glycemic response in subjects with impaired glucose tolerance and impaired fasting glucose and in healthy subjects: A crossover, randomized controlled trial. Nutr. Diabetes 2019, 9, 31. [CrossRef] [PubMed]

150. Zhao, L.; Sun, T.; Wang, L. Chitosan oligosaccharide improves the therapeutic efficacy of sitagliptin for the therapy of Chinese elderly patients with type 2 diabetes mellitus. Clin. Risk. Manag. 2017, 13, 739-750. [CrossRef]

151. Lupascu, F.G.; Giusca, S.E.; Caruntu, I.D.; Anton, A.; Lupusoru, C.E.; Profire, L. The safety profile of new antidiabetic xanthine derivatives and their chitosan based formulations. Eur. J. Pharm. Sci. 2019, 127, 71-78. [CrossRef]

152. Wang, J.; He, W.; Yang, D.; Cao, H.; Bai, Y.; Guo, J.; Su, Z. Beneficial Metabolic Effects of Chitosan and Chitosan Oligosaccharide on Epididymal WAT Browning and Thermogenesis in Obese Rats. Molecules 2019, 24. [CrossRef]

153. Yang, D.; Hu, C.; Deng, X.; Bai, Y.; Cao, H.; Guo, J.; Su, Z. Therapeutic Effect of Chitooligosaccharide Tablets on Lipids in High-Fat Diets Induced Hyperlipidemic Rats. Molecules 2019, 24. [CrossRef]

154. Deng, X.; Ye, Z.; Cao, H.; Bai, Y.; Che, Q.; Guo, J.; Su, Z. Chitosan oligosaccharide ameliorated obesity by reducing endoplasmic reticulum stress in diet-induced obese rats. Food. Funct. 2020, 11, 6285-6296. [CrossRef] [PubMed]

155. Liu, S.H.; Chen, R.Y.; Chiang, M.T. Effects of Chitosan Oligosaccharide on Plasma and Hepatic Lipid Metabolism and Liver Histomorphology in Normal Sprague-Dawley Rats. Mar. Drugs 2020, 18, 408. [CrossRef] 
156. Izumi, R.; Azuma, K.; Izawa, H.; Morimoto, M.; Nagashima, M.; Osaki, T.; Tsuka, T.; Imagawa, T.; Ito, N.; Okamoto, Y.; et al. Chitin nanofibrils suppress skin inflammation in atopic dermatitis-like skin lesions in NC/Nga mice. Carbohydr. Polym. 2016, 146, 320-327. [CrossRef] [PubMed]

157. Huang, C.J.; Beasley, K.N.; Acevedo, E.O.; Franco, R.L.; Jones, T.L.; Mari, D.C.; Shibata, Y. Chitin enhances obese inflammation ex vivo. Hum. Immunol. 2014, 75, 41-46. [CrossRef]

158. Van Dyken, S.J.; Mohapatra, A.; Nussbaum, J.C.; Molofsky, A.B.; Thornton, E.E.; Ziegler, S.F.; McKenzie, A.N.J.; Krummel, M.F.; Liang, H.E.; Locksley, R.M. Chitin activates parallel immune modules that direct distinct inflammatory responses via innate lymphoid type 2 and $\gamma \delta$ T cells. Immunity 2014, 40, 414-424. [CrossRef] [PubMed]

159. Arae, K.; Morita, H.; Unno, H.; Motomura, K.; Toyama, S.; Okada, N.; Ohno, T.; Tamari, M.; Orimo, K.; Mishima, Y.; et al. Chitin promotes antigen-specific Th2 cell-mediated murine asthma through induction of IL-33-mediated IL-1beta production by DCs. Sci. Rep. 2018, 8, 11721. [CrossRef]

160. Wagener, J.; Malireddi, R.K.S.; Lenardon, M.D.; Köberle, M.; Vautier, S.; MacCallum, D.M.; Biedermann, T.; Schaller, M.; Netea, M.G.; Kanneganti, T.D.; et al. Fungal Chitin Dampens Inflammation through IL-10 Induction Mediated by NOD2 and TLR9 Activation. PloS Pathog. 2014, 10. [CrossRef]

161. Danti, S.; Trombi, L.; Fusco, A.; Azimi, B.; Lazzeri, A.; Morganti, P.; Coltelli, M.B.; Donnarumma, G. Chitin Nanofibrils and Nanolignin as Functional Agents in Skin Regeneration. Int. J. Mol. Sci. 2019, 20, 2669. [CrossRef]

162. Wang, J.; Zhang, C.; Guo, C.; Li, X. Chitosan Ameliorates DSS-Induced Ulcerative Colitis Mice by Enhancing Intestinal Barrier Function and Improving Microflora. Int. J. Mol. Sci. 2019, 20, 5751. [CrossRef]

163. Gudmundsdottir, S.; Lieder, R.; Sigurjonsson, O.E.; Petersen, P.H. Chitosan leads to downregulation of YKL-40 and inflammasome activation in human macrophages. J. Biomed. Mater. Res. A 2015, 103, 2778-2785. [CrossRef]

164. Liu, Y.; Zong, S.; Li, J. Carboxymethyl chitosan perturbs inflammation profile and colonic microbiota balance in mice. J. Food Drug Anal. 2020, 28, 175-182. [CrossRef]

165. Yousef, M.; Pichyangkura, R.; Soodvilai, S.; Chatsudthipong, V.; Muanprasat, C. Chitosan oligosaccharide as potential therapy of inflammatory bowel disease: Therapeutic efficacy and possible mechanisms of action. Pharm. Res. 2012, 66, 66-79. [CrossRef] [PubMed]

166. Yang, Y.; Tong, Q.; Luo, H.; Huang, R.; Li, Z. Chitooligosaccharides attenuate lipopolysaccharide-induced inflammation and apoptosis of intestinal epithelial cells: Possible involvement of TLR4/NF- $\mathrm{B}$ pathway. Indian J. Pharm. Educ. Res. 2016, 50, 109-115. [CrossRef]

167. Xu, Q.; Liu, M.; Liu, Q.; Wang, W.; Du, Y.; Yin, H. The inhibition of LPS-induced inflammation in RAW264.7 macrophages via the PI3K/Akt pathway by highly $N$-acetylated chitooligosaccharide. Carbohydr. Polym. 2017, 174, 1138-1143. [CrossRef]

168. Sánchez, Á.; Mengíbar, M.; Fernández, M.; Alemany, S.; Heras, A.; Acosta, N. Influence of preparation methods of chitooligosaccharides on their physicochemical properties and their anti-inflammatory effects in mice and in RAW264.7 macrophages. Mar. Drugs 2018, 16, 430. [CrossRef] [PubMed]

169. Jiang, T.; Ji, H.; Zhang, L.; Wang, Y.; Zhou, H. Chitosan Oligosaccharide Exerts Anti-Allergic Effect against Shrimp Tropomyosin-Induced Food Allergy by Affecting Th1 and Th2 Cytokines. Int. Arch. Allergy Immunol. 2019, 180, 10-16. [CrossRef]

170. Lan, R.; Li, S.; Chang, Q.; Zhao, Z. Chitosan oligosaccharides protect sprague dawley rats from cyclic heat stress by attenuation of oxidative and inflammation stress. Animals 2019, 9, 1074. [CrossRef] [PubMed]

171. Wongkrasant, P.; Pongkorpsakol, P.; Chitwattananont, S.; Satianrapapong, W.; Tuangkijkul, N.; Muanprasat, C. Fructo-oligosaccharides alleviate inflammation-associated apoptosis of GLP-1 secreting L cells via inhibition of iNOS and cleaved caspase-3 expression. J. Pharm. Sci. 2020, 143, 65-73. [CrossRef]

172. Sun, Y.; Shi, X.; Zheng, X.; Nie, S.; Xu, X. Inhibition of dextran sodium sulfate-induced colitis in mice by baker's yeast polysaccharides. Carbohydr. Polym. 2019, 207, 371-381. [CrossRef]

173. Libreros, S.; Garcia-Areas, R.; Iragavarapu-Charyulu, V. CHI3L1 plays a role in cancer through enhanced production of pro-inflammatory/pro-tumorigenic and angiogenic factors. Immunol. Res. 2013, 57, 99-105. [CrossRef]

174. Libreros, S.; Garcia-Areas, R.; Shibata, Y.; Carrio, R.; Torroella-Kouri, M.; Iragavarapu-Charyulu, V. Induction of proinflammatory mediators by CHI3L1 is reduced by chitin treatment: Decreased tumor metastasis in a breast cancer model. Int. J. Cancer 2012, 131, 377-386. [CrossRef] [PubMed] 
175. Timoshenko, A.V. Chitin hydrolysate stimulates VEGF-C synthesis by MDAMB-231 breast cancer cells. Cell Biol. Int. 2011, 35, 281-286. [CrossRef] [PubMed]

176. Solairaj, D.; Rameshthangam, P.; Arunachalam, G. Anticancer activity of silver and copper embedded chitin nanocomposites against human breast cancer (MCF-7) cells. Int. J. Biol. Macromol. 2017, 105, 608-619. [CrossRef] [PubMed]

177. Singh, A.; Dutta, P.K.; Kumar, H.; Kureel, A.K.; Rai, A.K. Synthesis of chitin-glucan-aldehyde-quercetin conjugate and evaluation of anticancer and antioxidant activities. Carbohydr. Polym. 2018, 193, 99-107. [CrossRef] [PubMed]

178. Arunraj, T.R.; Sanoj Rejinold, N.; Ashwin Kumar, N.; Jayakumar, R. Bio-responsive chitin-poly(l-lactic acid) composite nanogels for liver cancer. Colloids Surf. B 2014, 113, 394-402. [CrossRef]

179. Pirzadeh-Naeeni, S.; Mozdianfard, M.R.; Shojaosadati, S.A.; Khorasani, A.C.; Saleh, T. A comparative study on schizophyllan and chitin nanoparticles for ellagic acid delivery in treating breast cancer. Int. J. Biol. Macromol. 2020, 144, 380-388. [CrossRef]

180. Gibot, L.; Chabaud, S.; Bouhout, S.; Bolduc, S.; Auger, F.A.; Moulin, V.J. Anticancer properties of chitosan on human melanoma are cell line dependent. Int. J. Biol. Macromol. 2015, 72, 370-379. [CrossRef]

181. Mattaveewong, T.; Wongkrasant, P.; Chanchai, S.; Pichyangkura, R.; Chatsudthipong, V.; Muanprasat, C. Chitosan oligosaccharide suppresses tumor progression in a mouse model of colitis-associated colorectal cancer through AMPK activation and suppression of NF-kappaB and mTOR signaling. Carbohydr. Polym. 2016, 145, 30-36. [CrossRef]

182. Li, H.F.; Huang, L.F.; Chen, L.H. Chitooligosaccharides inhibit A549 lung cancer cell line proliferation by regulating cell autophagy. J. Biol. Regul. Homeost. Agents 2019, 33, 1527-1532.

183. Wimardhani, Y.S.; Suniarti, D.F.; Freisleben, H.J.; Wanandi, S.I.; Siregar, N.C.; Ikeda, M.A. Chitosan exerts anticancer activity through induction of apoptosis and cell cycle arrest in oral cancer cells. J. Oral. Sci. 2014, 56, 119-126. [CrossRef]

184. Abedian, Z.; Moghadamnia, A.A.; Zabihi, E.; Pourbagher, R.; Ghasemi, M.; Nouri, H.R.; Tashakorian, H.; Jenabian, N. Anticancer properties of chitosan against osteosarcoma, breast cancer and cervical cancer cell lines. Casp. J. Intern. Med. 2019, 10, 439-446. [CrossRef]

185. Tan, G.; Kaya, M.; Tevlek, A.; Sargin, I.; Baran, T. Antitumor activity of chitosan from mayfly with comparison to commercially available low, medium and high molecular weight chitosans. In Vitro Cell Dev. Biol. Anim. 2018, 54, 366-374. [CrossRef] [PubMed]

186. Srinivasan, H.; Kanayairam, V.; Ravichandran, R. Chitin and chitosan preparation from shrimp shells Penaeus monodon and its human ovarian cancer cell line, PA-1. Int. J. Biol. Macromol. 2018, 107, 662-667. [CrossRef] [PubMed]

187. Jiang, Z.; Han, B.; Li, H.; Yang, Y.; Liu, W. Carboxymethyl chitosan represses tumor angiogenesis in vitro and in vivo. Carbohydr. Polym. 2015, 129, 1-8. [CrossRef] [PubMed]

188. Gao, J.; Zhao, Y.; Wang, C.; Ji, H.; Yu, J.; Liu, C.; Liu, A. A novel synthetic chitosan selenate (CS) induces apoptosis in A549 lung cancer cells via the Fas/FasL pathway. Int. J. Biol. Macromol. 2020, 158, 689-697. [CrossRef] [PubMed]

189. Hasanzade, Z.; Raissi, H. Assessment of the chitosan-functionalized graphene oxide as a carrier for loading thioguanine, an antitumor drug and effect of urea on adsorption process: Combination of DFT computational and molecular dynamics simulation studies. J. Biomol. Struct. Dyn. 2019, 37, 2487-2497. [CrossRef]

190. Lee, J.Y.; Termsarasab, U.; Lee, M.Y.; Kim, D.H.; Lee, S.Y.; Kim, J.S.; Cho, H.J.; Kim, D.D. Chemosensitizing indomethacin-conjugated chitosan oligosaccharide nanoparticles for tumor-targeted drug delivery. Acta. Biomater. 2017, 57, 262-273. [CrossRef]

191. Li, P.W.; Wang, G.; Yang, Z.M.; Duan, W.; Peng, Z.; Kong, L.X.; Wang, Q.H. Development of drug-loaded chitosan-vanillin nanoparticles and its cytotoxicity against HT-29 cells. Drug Deliv. 2016, 23, 30-35. [CrossRef]

192. Hafsa, J.; Smach, M.A.; Charfeddine, B.; Limem, K.; Majdoub, H.; Rouatbi, S. Antioxidant and antimicrobial proprieties of chitin and chitosan extracted from Parapenaeus Longirostris shrimp shell waste. Ann. Pharm. Fr. 2016, 74, 27-33. [CrossRef]

193. Morganti, P.; Fabrizi, G.; Palombo, P.; Palombo, M.; Guarneri, F.; Cardillo, A.; Morganti, G. New chitin complexes and their anti-aging activity from inside out. J. Nutr. Health Aging 2012, 16, 242-245. [CrossRef]

194. Morganti, P.; Morganti, G.; Colao, C. Biofunctional Textiles for Aging Skin. Biomedicines 2019, 7. [CrossRef] [PubMed] 
195. Anandan, R.; Ganesan, B.; Obulesu, T.; Mathew, S.; Asha, K.K.; Lakshmanan, P.T.; Zynudheen, A.A. Antiaging effect of dietary chitosan supplementation on glutathione-dependent antioxidant system in young and aged rats. Cell Stress Chaperones 2013, 18, 121-125. [CrossRef]

196. Qiao, Y.; Bai, X.F.; Du, Y.G. Chitosan oligosaccharides protect mice from LPS challenge by attenuation of inflammation and oxidative stress. Int. Immunopharmacol. 2011, 11, 121-127. [CrossRef] [PubMed]

197. Zhang, C.M.; Yu, S.H.; Zhang, L.S.; Zhao, Z.Y.; Dong, L.L. Effects of several acetylated chitooligosaccharides on antioxidation, antiglycation and NO generation in erythrocyte. Bioorg. Med. Chem. Lett. 2014, 24, 4053-4057. [CrossRef] [PubMed]

198. Wei, L.; Li, Y.; Chang, Q.; Guo, G.; Lan, R. Effects of chitosan oligosaccharides on intestinal oxidative stress and inflammation response in heat stressed rats. Exp. Anim. 2020, 20-0085. [CrossRef] [PubMed]

199. Lan, R.; Chang, Q.; An, L.; Zhao, Z. Dietary Supplementation with Chitosan Oligosaccharides Alleviates Oxidative Stress in Rats Challenged with Hydrogen Peroxide. Animals 2019, 10. [CrossRef]

200. Xu, Y.Q.; Xing, Y.Y.; Wang, Z.Q.; Yan, S.M.; Shi, B.L. Pre-protective effects of dietary chitosan supplementation against oxidative stress induced by diquat in weaned piglets. Cell Stress Chaperones 2018, 23, 703-710. [CrossRef]

201. Kong, S.-Z.; Li, J.-C.; Li, S.-D.; Liao, M.-N.; Li, C.-P.; Zheng, P.-J.; Guo, M.-H.; Tan, W.-X.; Zheng, Z.-H.; Hu, Z. Anti-Aging Effect of Chitosan Oligosaccharide on d-Galactose-Induced Subacute Aging in Mice. Mar. Drugs 2018, 16, 181. [CrossRef]

202. Wang, Y.; Xiong, Y.; Zhang, A.; Zhao, N.; Zhang, J.; Zhao, D.; Yu, Z.; Xu, N.; Yin, Y.; Luan, X.; et al. Oligosaccharide attenuates aging-related liver dysfunction by activating Nrf2 antioxidant signaling. Food Sci. Nutr. 2020, 8, 3872-3881. [CrossRef]

203. Chen, F.; Hou, L.; Zhu, L.; Chengbo, Y.; Zhu, F.; Qiu, H.; Qin, S. Effects of selenide chitosan sulfate on glutathione system in hepatocytes and specific pathogen-free chickens. Poult. Sci. 2020, 99, 3979-3986. [CrossRef]

204. Chaiwong, N.; Leelapornpisid, P.; Jantanasakulwong, K.; Rachtanapun, P.; Seesuriyachan, P.; Sakdatorn, V.; Leksawasdi, N.; Phimolsiripol, Y. Antioxidant and Moisturizing Properties of Carboxymethyl Chitosan with Different Molecular Weights. Polymers 2020, 12, 1445. [CrossRef] [PubMed]

205. Ahlawat, J.; Neupane, R.; Deemer, E.; Sreenivasan, S.T.; Narayan, M. Chitosan-Ellagic Acid Nanohybrid for Mitigating Rotenone-induced Oxidative Stress. ACS Appl. Mater. Interfaces 2020, 12, 18964-18977. [CrossRef] [PubMed]

206. Park, H.H.; Ko, S.C.; Oh, G.W.; Jang, Y.M.; Kim, Y.M.; Park, W.S.; Choi, I.W.; Jung, W.K. Characterization and biological activity of PVA hydrogel containing chitooligosaccharides conjugated with gallic acid. Carbohydr. Polym. 2018, 198, 197-205. [CrossRef]

207. Tachaboonyakiat, W.; Sukpaiboon, E.; Pinyakong, O. Development of an antibacterial chitin betainate wound dressing. Polym. J. 2014, 46, 505-510. [CrossRef]

208. Kovalchuk, V.; Voronkina, A.; Binnewerg, B.; Schubert, M.; Muzychka, L.; Wysokowski, M.; Tsurkan, M.V.; Bechmann, N.; Petrenko, I.; Fursov, A.; et al. Naturally Drug-Loaded Chitin: Isolation and Applications. Mar. Drugs 2019, 17, 574. [CrossRef] [PubMed]

209. Khan, F.; Lee, J.W.; Pham, D.T.N.; Kim, Y.M. Chitooligosaccharides as antibacterial, antibiofilm, antihemolytic and anti-virulence agent against staphylococcus aureus. Curr. Pharm. Biotechnol. 2019, 20, 1223-1233. [CrossRef]

210. Ahmed, S.A.; El-Mahallawy, H.S.; Karanis, P. Inhibitory activity of chitosan nanoparticles against Cryptosporidium parvum oocysts. Parasitol. Res. 2019, 118, 2053-2063. [CrossRef]

211. Mammeri, M.; Chevillot, A.; Thomas, M.; Polack, B.; Julien, C.; Marden, J.P.; Auclair, E.; Vallee, I.; Adjou, K.T. Efficacy of chitosan, a natural polysaccharide, against Cryptosporidium parvum in vitro and in vivo in neonatal mice. Exp. Parasitol. 2018, 194, 1-8. [CrossRef]

212. Arias, L.S.; Butcher, M.C.; Short, B.; McKloud, E.; Delaney, C.; Kean, R.; Monteiro, D.R.; Williams, C.; Ramage, G.; Brown, J.L. Chitosan Ameliorates Candida auris Virulence in a Galleria mellonella Infection Model. Antimicrob. Agents Chemother. 2020, 64. [CrossRef]

213. Ganan, M.; Lorentzen, S.B.; Agger, J.W.; Heyward, C.A.; Bakke, O.; Knutsen, S.H.; Aam, B.B.; Eijsink, V.G.H.; Gaustad, P.; Sørlie, M. Antifungal activity of well-defined chito-oligosaccharide preparations against medically relevant yeasts. PLoS ONE 2019, 14, e0210208. [CrossRef] 
214. Li, T.; Zhang, Y.; Xu, M.; Liu, Y.; Zhang, C.; Zhang, Y.; Peng, X.; Li, Z.; Qin, S.; Xing, K. Novel antifungal mechanism of oligochitosan by triggering apoptosis through a metacaspase-dependent mitochondrial pathway in Ceratocystis fimbriata. Carbohydr. Polym. 2020, 245, 116574. [CrossRef] [PubMed]

215. Zhang, J.; Tan, W.; Li, Q.; Dong, F.; Guo, Z. Synthesis and Characterization of N,N,N-trimethyl-O(ureidopyridinium)acetyl Chitosan Derivatives with Antioxidant and Antifungal Activities. Mar. Drugs 2020, 18, 163. [CrossRef] [PubMed]

216. Mei, L.; Xu, Z.; Shi, Y.; Lin, C.; Jiao, S.; Zhang, L.; Li, P. Multivalent and synergistic chitosan oligosaccharide-Ag nanocomposites for therapy of bacterial infection. Sci. Rep. 2020, 10, 10011. [CrossRef] [PubMed]

217. Khan, F.; Lee, J.W.; Manivasagan, P.; Pham, D.T.N.; Oh, J.; Kim, Y.M. Synthesis and characterization of chitosan oligosaccharide-capped gold nanoparticles as an effective antibiofilm drug against the Pseudomonas aeruginosa PAO1. Microb. Pathog. 2019, 135. [CrossRef]

218. Liu, X.; Xia, W.; Jiang, Q.; Yu, P.; Yue, L. Chitosan oligosaccharide-N-chlorokojic acid mannich base polymer as a potential antibacterial material. Carbohydr. Polym. 2018, 182, 225-234. [CrossRef]

219. Nakajima, M.; Atsumi, K.; Kifune, K. Chitin is an effective material for sutures. Jpn. J. Surg. 1986, 16, 418-424. [CrossRef]

220. Klinger, C.; Żółtowska-Aksamitowska, S.; Wysokowski, M.; Tsurkan, M.V.; Galli, R.; Petrenko, I.; Machałowski, T.; Ereskovsky, A.; Martinović, R.; Muzychka, L.; et al. Express Method for Isolation of Ready-to-Use 3D Chitin Scaffolds from Aplysina archeri (Aplysineidae: Verongiida) Demosponge. Mar. Drugs 2019, 17, 131. [CrossRef]

221. Shao, K.; Han, B.; Gao, J.; Jiang, Z.; Liu, W.; Liu, W.; Liang, Y. Fabrication and feasibility study of an absorbable diacetyl chitin surgical suture for wound healing. J. Biomed. Mater. Res. B 2016, 104, 116-125. [CrossRef]

222. Balitaan, J.N.I.; Hsiao, C.D.; Yeh, J.M.; Santiago, K.S. Innovation inspired by nature: Biocompatible self-healing injectable hydrogels based on modified- $\beta$-chitin for wound healing. Int. J. Biol. Macromol. 2020, 162, 723-736. [CrossRef]

223. Chao, F.C.; Wu, M.H.; Chen, L.C.; Lin, H.L.; Liu, D.Z.; Ho, H.O.; Sheu, M.T. Preparation and characterization of chemically TEMPO-oxidized and mechanically disintegrated sacchachitin nanofibers (SCNF) for enhanced diabetic wound healing. Carbohydr. Polym. 2020, 229, 115507. [CrossRef]

224. Zhong, Z.; Huang, Y.; Hu, Q.; He, W.; Duan, B.; Yan, X.; Yang, Z.; Liang, W.; Liu, Z.; Peng, Z.; et al. Elucidation of molecular pathways responsible for the accelerated wound healing induced by a novel fibrous chitin dressing. Biomater. Sci. 2019, 7, 5247-5257. [CrossRef]

225. Kuwabara, M.; Sato, Y.; Ishihara, M.; Takayama, T.; Nakamura, S.; Fukuda, K.; Murakami, K.; Yokoe, H.; Kiyosawa, T. Healing of Pseudomonas aeruginosa-infected wounds in diabetic $\mathrm{db} / \mathrm{db}$ mice by weakly acidic hypochlorous acid cleansing and silver nanoparticle/chitin-nanofiber sheet covering. Wound Med. 2020, 28. [CrossRef]

226. Zhou, D.; Yang, R.; Yang, T.; Xing, M.; Luo, G. Preparation of chitin-amphipathic anion/ quaternary ammonium salt ecofriendly dressing and its effect on wound healing in mice. Int. J. Nanomed. 2018, 13, 4157-4169. [CrossRef] [PubMed]

227. Abudula, T.; Gauthaman, K.; Mostafavi, A.; Alshahrie, A.; Salah, N.; Morganti, P.; Chianese, A.; Tamayol, A.; Memic, A. Sustainable drug release from polycaprolactone coated chitin-lignin gel fibrous scaffolds. Sci. Rep. 2020, 10, 20428. [CrossRef] [PubMed]

228. Pang, J.; Bi, S.; Kong, T.; Luo, X.; Zhou, Z.; Qiu, K.; Huang, L.; Chen, X.; Kong, M. Mechanically and functionally strengthened tissue adhesive of chitin whisker complexed chitosan/dextran derivatives based hydrogel. Carbohydr. Polym. 2020, 237, 116138. [CrossRef]

229. Maevskaia, E.N.; Shabunin, A.S.; Dresvyanina, E.N.; Dobrovol'skaya, I.P.; Yudin, V.E.; Paneyah, M.B.; Fediuk, A.M.; Sushchinskii, P.L.; Smirnov, G.P.; Zinoviev, E.V.; et al. Influence of the Introduced Chitin Nanofibrils on Biomedical Properties of Chitosan-Based Materials. Nanomaterials 2020, 10, 945. [CrossRef]

230. Li, Z.W.; Li, C.W.; Wang, Q.; Shi, S.J.; Hu, M.; Zhang, Q.; Cui, H.H.; Sun, J.B.; Zhou, M.; Wu, G.L.; et al. The cellular and molecular mechanisms underlying silver nanoparticle/chitosan oligosaccharide/poly(vinyl alcohol) nanofiber-mediated wound healing. J. Biomed. Nanotechnol. 2017, 13, 17-34. [CrossRef]

231. Li, C.W.; Wang, Q.; Li, J.; Hu, M.; Shi, S.J.; Li, Z.W.; Wu, G.L.; Cui, H.H.; Li, Y.Y.; Zhang, Q.; et al. Silver nanoparticles/chitosan oligosaccharide/poly(vinyl alcohol) nanofiber promotes wound healing by activating TGFß1/Smad signaling pathway. Int. J. Nanomed. 2016, 11, 373-387. [CrossRef] 
232. Cifuentes, A.; Gomez-Gil, V.; Ortega, M.A.; Asunsolo, A.; Coca, S.; Roman, J.S.; Alvarez-Mon, M.; Bujan, J.; Garcia-Honduvilla, N. Chitosan hydrogels functionalized with either unfractionated heparin or bemiparin improve diabetic wound healing. Biomed. Pharm. 2020, 129, 110498. [CrossRef]

233. Natarajan, J.; Sanapalli, B.K.R.; Bano, M.; Singh, S.K.; Gulati, M.; Karri, V. Nanostructured Lipid Carriers of Pioglitazone Loaded Collagen/Chitosan Composite Scaffold for Diabetic Wound Healing. Adv. Wound Care (New Rochelle) 2019, 8, 499-513. [CrossRef]

234. Viezzer, C.; Mazzuca, R.; Machado, D.C.; de Camargo Forte, M.M.; Gomez Ribelles, J.L. A new waterborne chitosan-based polyurethane hydrogel as a vehicle to transplant bone marrow mesenchymal cells improved wound healing of ulcers in a diabetic rat model. Carbohydr. Polym. 2020, 231, 115734. [CrossRef] [PubMed]

235. Xia, G.; Zhai, D.; Sun, Y.; Hou, L.; Guo, X.; Wang, L.; Li, Z.; Wang, F. Preparation of a novel asymmetric wettable chitosan-based sponge and its role in promoting chronic wound healing. Carbohydr. Polym. 2020, 227, 115296. [CrossRef] [PubMed]

236. Nguyen, M.H.; Lee, S.E.; Tran, T.T.; Bui, C.B.; Nguyen, T.H.N.; Vu, N.B.D.; Tran, T.T.; Nguyen, T.H.P.; Nguyen, T.T.; Hadinoto, K. A simple strategy to enhance the in vivo wound-healing activity of curcumin in the form of self-assembled nanoparticle complex of curcumin and oligochitosan. Mater. Sci. Eng. C Mater. Biol. Appl. 2019, 98, 54-64. [CrossRef] [PubMed]

237. Lv, X.; Liu, Y.; Song, S.; Tong, C.; Shi, X.; Zhao, Y.; Zhang, J.; Hou, M. Influence of chitosan oligosaccharide on the gelling and wound healing properties of injectable hydrogels based on carboxymethyl chitosan/alginate polyelectrolyte complexes. Carbohydr. Polym. 2019, 205, 312-321. [CrossRef]

238. Niho, N.; Tamura, T.; Toyoda, K.; Uneyama, C.; Shibutani, M.; Hirose, M. A 13-week subchronic toxicity study of chitin in F344 rats. Kokuritsu Iyakuhin Shokuhin Eisei Kenkyusho Hokoku 1999, 117, 129-134.

239. Mohammed, M.A.; Syeda, J.T.M.; Wasan, K.M.; Wasan, E.K. An Overview of Chitosan Nanoparticles and Its Application in Non-Parenteral Drug Delivery. Pharmaceutics 2017, 9, 53. [CrossRef]

240. Bellich, B.; D'Agostino, I.; Semeraro, S.; Gamini, A.; Cesàro, A. "The Good, the Bad and the Ugly" of Chitosans. Mar. Drugs 2016, 14, 99. [CrossRef]

Publisher's Note: MDPI stays neutral with regard to jurisdictional claims in published maps and institutional affiliations.

(C) 2020 by the authors. Licensee MDPI, Basel, Switzerland. This article is an open access article distributed under the terms and conditions of the Creative Commons Attribution (CC BY) license (http://creativecommons.org/licenses/by/4.0/). 